Article

\title{
The Influence of Dissolved Organic Carbon on the Microbial Community Associated with Tetraselmis striata for Bio-Diesel Production
}

\author{
Sae-Hee Kim ${ }^{1,+}{ }^{\dagger}$ Jin Ho Kim ${ }^{1,2,3,+}{ }^{\circ}$, Seung Ho Baek ${ }^{2}{ }^{\oplus}$, Joo-Hwan Kim ${ }^{1,4}$, \\ Penelope A. Ajani ${ }^{5}{ }^{(0)}$, Bum Soo Park ${ }^{6, *}{ }^{-1}$ and Myung-Soo Han ${ }^{1, *}$ \\ 1 Department of Life Science, College of Natural Sciences, Hanyang University, Seoul 04763, Korea; \\ briganitia@hanyang.ac.kr (S.-H.K.); diatomist.jin@gmail.com (J.H.K.); jhkim87@korea.kr (J.-H.K.) \\ 2 Risk Assessment Research Center, Korea Institute of Ocean Science and Technology, Geoje 53201, Korea; \\ baeksh@kiost.ac.kr \\ 3 DNA Analysis Division, National Forensic Service, Seoul 158-707, Korea \\ 4 Han River Basin Environmental Office, Ministry of Environment, 231-0, Hanam-si, \\ Gyeonggi-do 12902, Korea \\ 5 Climate Change Cluster (C3), University of Technology Sydney, Ultimo 2007, Australia; \\ Penelope.Ajani@uts.edu.au \\ 6 Marine Ecosystem Research Center, Korea Institute of Ocean Science and Technology, Busan 49111, Korea \\ * Correspondence: parkbs@kiost.ac.kr (B.S.P.); hanms@hanyang.ac.kr (M.-S.H.); Tel.: +82-51-664-3336 (B.S.P.); \\ +82-2-2220-0956 (M.-S.H.) \\ + The first two authors are co-first authors.
}

Received: 29 April 2020; Accepted: 18 May 2020; Published: 22 May 2020

check for updates

Featured Application: The following topics are assessed in this study: (1) microbial disturbance due to dissolved organic carbon secreted from $T$. striata; (2) risk of large-scale microalgae cultivation to marine environment; (3) relationship between bacteria and phytoplankton by dissolved organic carbon; (4) ecosystem impact assessment through mesocosm study.

\begin{abstract}
The green alga Tetraselmis striata is regarded as a suitable candidate microalga for bio-diesel production. Recently, T. striata was cultured near Yeonghueung Island, Korea, in a "marine culturing field"; however, its environmental impacts are not yet studied. We estimated the amount of dissolved organic carbon (DOC) released from T. striata cultivation in the marine culturing field, and we investigated the changes in bacterial composition. Then, we designed and installed a mesocosm for further understanding. From the mesocosm results, the DOC released from the cultivation of T. striata led to changes in bacterial communities, disturbance of the microbial food web structure, rapid depletion of nutrients, and a decrease in dissolved oxygen (DO) and $\mathrm{pH}$. Our novel work demonstrates that large amounts of DOC secreted by large-scale microalgal cultures such as that of T. striata can potentially have a significant impact on the structure and function of the surrounding microbial ecosystem.
\end{abstract}

Keywords: Tetraselmis; DOC; bacterial community; microbial disturbance; food web structure; mesocosm

\section{Introduction}

Over the past two decades, the cultivation of microalgae as a source of sustainable biomass for the production of biofuels gained much attention [1,2]. Marine microalgae cultivation is relatively low cost, has a low space requirement, and can utilize a natural source of nutrients for algal growth [3]. The green alga Tetraselmis sp. (Chlorodendraceae) is regarded as a suitable candidate microalga for 
bio-diesel production due to its high lipid content and fast growth $[1,4,5]$. As a consequence, various studies were carried out to search for the optimal growth conditions of this species [6-8] and to increase the lipid content using genetic, biotic, and environmental manipulations [9-13].

More recently, Tetraselmis striata was cultured near Yeonghueung Island, Korea, in a "marine culturing field" - a floating marine system which uses semi-permeable membranes for cost-effective mass cultivation [14,15] (Figure 1). This system also uses minimal power for temperature control, as well as a minimal supply of nutrients, and it requires insignificant mixing compared to conventional, large-scale algal culturing systems [16-19]. This large culturing facility, however, may pose adverse effects on the surrounding marine environment, many of which are yet to be investigated. Firstly, this large-scale marine culturing field may cause detrimental effects to the underlying benthic ecosystem by obstructing light usually transmitted through the water column [20-22]. Secondly, any damage to the culturing marine culturing field due to natural disasters such as typhoons or tsunamis may cause large quantities of microalgae to be released into the natural ecosystem. Finally, large quantities of dissolved organic matter (DOM) are continually released into the environment from this facility due to the use of semi-permeable membranes [23,24]. While reduced light transmission and natural disasters are localized events, the release of DOM into the coastal environment can be significant, resulting in coastal eutrophication and the potential for other microalgal blooms to occur including those that are harmful. The DOM released by phytoplankton is also a ubiquitous process, often resulting in $2 \%-50 \%$ of the carbon fixed by photosynthesis leaving the cell [25]. This supply of carbon is thought to be the main autochthonous source of dissolved organic carbon (DOC) into marine ecosystems and a major source of carbon for heterotrophic prokaryotes [25]. A subsequent change in the release of DOC into the marine environment may also cause a change in bacterial composition within the microbial ecosystem [26-28]. As these bacterial communities form the basis of microbial food webs, playing a significant role in marine biogeochemical cycling and energy transfer, any change in their community structure is likely to also affect organisms at higher trophic levels [29,30]. Indeed, recent research by Wang et al. (2017) [31] showed that the DOC measured near Yeongheung Island appeared to be an important factor affecting the abundance and composition of bacteria and phytoplankton in this area.

At present, the size of the marine culturing field near Yeonghueung Island, Korea, gradually expanded to 1 ha $\left(10,000 \mathrm{~m}^{2}\right)$ with the capacity to cultivate 280 tons of T. striata. Whilst the size of the marine culturing field gradually expanded, the environmental impacts are yet to be studied. It is hypothesized that a large amount of DOC entering the region may change the composition of bacteria, and a sudden bloom of T. striata may inhibit the growth of other competitive organisms and/or affect organisms at higher or lower trophic levels. With this in mind, we firstly estimated amount of DOC released from T. striata culture when the marine culturing field was in operation, and we compared the bacterial composition inside and outside of the semi-permeable membrane in which T. striata was cultured. After confirming the effect of DOC on the bacterial community composition, a mesocosm experiment was then designed and carried out to gain a more in-depth understanding of the influence of DOC release from this T. striata cultivation on the surrounding water column physicochemical properties, bacterial community, and microbial food web structure. 

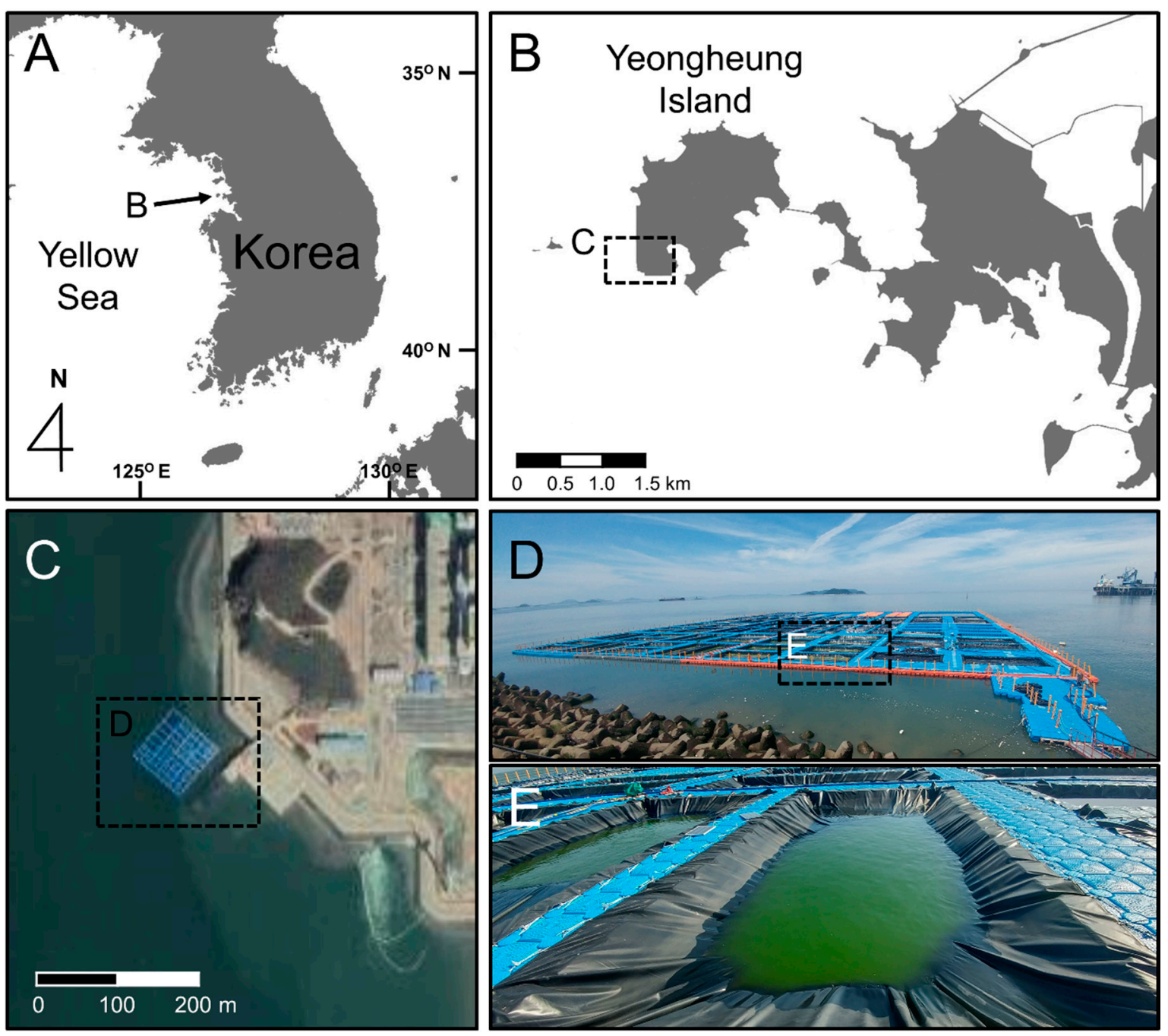

Figure 1. National (A) and regional (B) locations where the "marine culturing field" is located, viewed

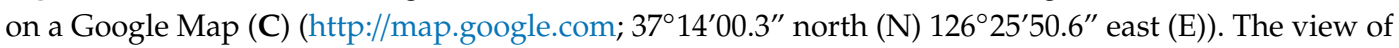
the operating marine culturing field (D), and the installed cultivation pond made using semi-permeable membrane (E).

\section{Materials and Methods}

\subsection{Tetraselmis striata Strain and Culturing}

The Tetraselmis striata strain (KCTC12432BP) used in this study was obtained from the Department of Biological Engineering, Inha University, Incheon, South Korea, and maintained under axenic conditions [28] to exclude any phycosperic and/or symbiont bacterial effect. Prior to the experiment beginning, the strain of T. striata was checked for any bacterial contamination using 4' ${ }^{\prime}$,6-diamidino-2-phenylindole (DAPI) staining and observation using a fluorescence microscope (BX51, Olympus, Japan) [28]. Ten liters of T. striata stock culture was maintained using $\mathrm{f} / 2$ media [32] at $20{ }^{\circ} \mathrm{C}$ exposed to cool-white fluorescent lamps of $50 \mathrm{mmol}$ photons $\cdot \mathrm{m}^{-2} \cdot \mathrm{s}^{-1}$ under a $12-\mathrm{h} / 12-\mathrm{h}$ light/dark photoperiod cycles until the experiment began.

\subsection{Sampling of Marine Culturing Field}

Culturing of T. striata for bio-diesel biomass was carried out from May to November 2016 using 30 floating cultivations, each $3 \mathrm{~m}$ wide and $10 \mathrm{~m}$ in length, made using semi-permeable membranes with a total holding capacity of nine tons of seawater (Figure 1) The ponds were initially inoculated 
with $T$. striata at a cell density of $9.1 \times 10^{4}$ cells $\cdot \mathrm{mL}^{-1}$. From the surface of one randomly selected pond, a 1.0-L sample of T. striata was sampled on days $0,1,2,3,5,7$, and 9 to measure the changes in cell density of T. striata and the concentration of DOC over time (Section 2.4). From each of these samples, a 50-mL subsample was preserved with 5\% Lugol's solution [33] and returned to the laboratory for cell enumeration. A Sedgewick-Rafter counting chamber (Rigosha Co., Tokyo, Japan) was used to estimate the number of T. striata using light microscopy (Axioplan, Zeiss, Jena, Germany) at $400 \times$ magnification. Another set of 0.5-L samples were collected on days 0,3 , and 9 to analyze the bacterial composition of the cultivation pond (Section 2.5). Finally, a 1.0-L sample of seawater was collected from the surface approximately three meters away from the marine culturing field for comparison to the DOC and bacterial composition.

\subsection{Mesocosm Design and Sampling}

Four mesocosms (each one ton) were set up to evaluate the impacts of T. striata cultivation on the surrounding bacterial community and the microbial ecosystem-see below (Figure 2). Mesocosms were floated by buoys and tied to the pier using ropes (Figure 2B). Each mesocosm was filled with one ton of natural seawater and then left for two days for acclimation. A 20-L bioreactor containing T. striata enclosed by a semi-permeable membrane was then installed into two of the mesocosms and secured with ropes. These are termed "bioreactor installed mesocosms" (BMs) for the duration of the study. The other two adjacent mesocosms had no bioreactors installed, and they are termed "control mesocosms" (CMs) (Figure 2A,C,D). All mesocosms (BMs and CMs) were then spiked with $30 \mu \mathrm{M}$ nitrate and $2 \mu \mathrm{M}$ phosphate to induce sufficient growth of all biota living in mesocosms. On days 0,2 , $3,4,5,6,7,9,11,13$, and 15, four liters of seawater was subsampled from each mesocosm for DOC concentration, as well as various biotic factors (bacterial abundance and composition, abundances of heterotrophic nano-flagellates (HNF), phytoplankton, ciliates, and zooplankton, and the nutrients ammonium, nitrate, nitrite, phosphate and silicate) (see below). On each day, a 50-mL sample of T. striata was also collected using a suction flask through tubes which connected to the faucet of each bioreactor (Figure 2C,E). This water sample was subsequently preserved with 5\% Lugol's solution [33] and returned to the laboratory for cell enumeration. Water temperature $\left({ }^{\circ} \mathrm{C}\right)$, salinity, $\mathrm{pH}$, and dissolved oxygen (DO, $\mathrm{mg} \cdot \mathrm{L}^{-1}$ ) were also measured within and adjacent to ( $3 \mathrm{~m}$ away) mesocosms using an YSI 6600 sonde (YSI inc., Marion, MA, USA).

\subsection{DOC Analysis}

To analyze the total concentration of DOC, seawater samples were collected by passing $50 \mathrm{~mL}$ of the filtrate through a pre-combusted $\left(400^{\circ} \mathrm{C}\right.$ for $8 \mathrm{~h}$ ) GF/F filter (Whatman, Middlesex, U.K.) in a pre-combusted $\left(400^{\circ} \mathrm{C}\right.$ for $8 \mathrm{~h}$ ) total organic carbon (TOC) vial (Shimadzu, Kyoto, Japan) and fixed with $2 \% \mathrm{H}_{2} \mathrm{PO}_{4}$ (final concentration) to protect the total amount of DOC from any further biological activity. The samples were then stored at $4{ }^{\circ} \mathrm{C}$ until measured using a TOC Analyzer (Shimadzu, Kyoto, Japan). To characterize the DOC, 0.5 -L subsamples were filtered with a $47-\mathrm{mm}$-diameter GF/F filter (Whatman, Middlesex, U.K.) and the filtrates were stored at $-80^{\circ} \mathrm{C}$ in the dark until further analysis. Synchronous fluorescence spectra of the DOC were estimated using a luminescence fluorometer (FS-55, Scinco, Korea) with a constant offset $(\Delta \lambda=30 \mathrm{~nm})$, based on the protocol of Hur et al. (2008) [34]. Four regions were allocated to the integrated areas of the fluorescence intensities: $250-300 \mathrm{~nm}$ for protein-like fluorescence (PLF); 300-380 nm for fulvic-like fluorescence (FLF); 380-420 nm for humic-like fluorescence (HLF); 420-600 nm for terrestrial humic-like fluorescence (THLF) [35]. For discrete data, integration was made by the summation of the fluorescence intensities at the interval of $1 \mathrm{~nm}$. Each relative fluorescence region was then calculated over the whole fluorescence intensity as \%PLF, $\%$ FLF, \%HLF, and \%THLF, respectively. 


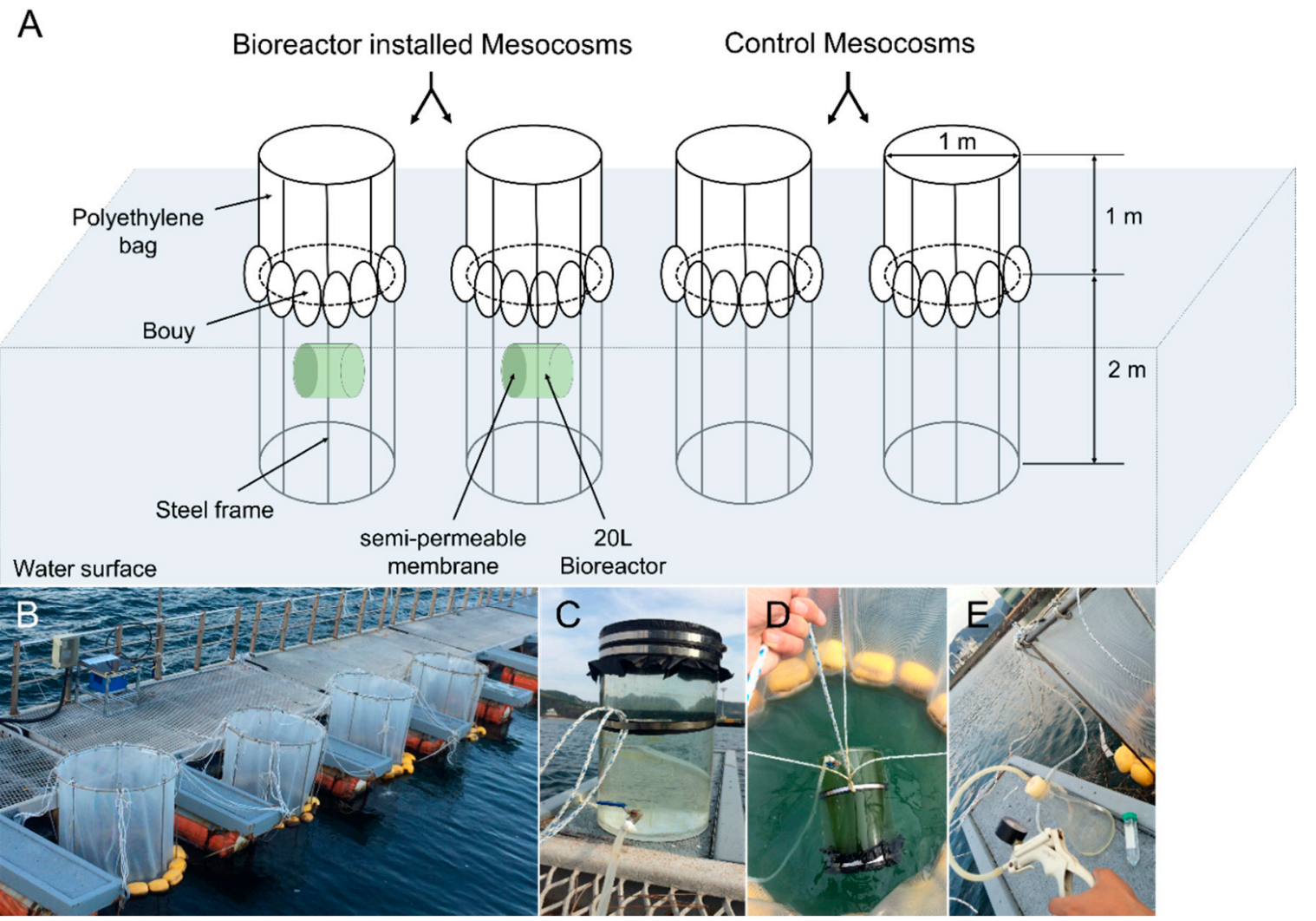

Figure 2. Schematic diagram designed four mesocosms for this study (A), and installed mesocosms at pier using ropes (B). Bioreactor $(20 \mathrm{~L})$ of Tetraselmis striata enclosed with semi-permeable membrane (C) and installed view in mesocosm using ropes (D). Sampling for T. striata cells using a suction flask through tubes which connected to the faucet of each bioreactor (E).

\subsection{Bacterial Abundance and Composition}

To determine the abundance of bacteria in each water sample collected, a 10-mL subsample was preserved with $2 \%$ glutaraldehyde final concentration (Sigma-Aldrich, St. Louis, MO, USA) and stored in the dark at room temperature until further processing. Preserved samples were then filtered using a 0.2- $\mu \mathrm{m}$-pore GTTP Millipore filter membrane (Millipore Filter Corporation, Cork, Ireland) and stained using the DAPI method [36]. The bacterial cells were enumerated using an Olympus epifluorescence microscope (XC10, Olympus, Tokyo, Japan) under 1000× magnification.

Next-generation sequencing (NGS) was used to analyze the bacterial community. For DNA extraction, a 0.5-L seawater sample obtained from each experiment was filtered onto a 0.2- $\mu \mathrm{m}$-pore and 47-mm-diameter ISOPORE membrane filter (MILLIPORE, Cork, Ireland). Loaded filters were placed in a 2-mL micro-tube (Axygen Sciences, CA, USA) which contained $800 \mathrm{~mL}$ of extraction buffer (100 mM Tris- $\mathrm{HCl}, 100 \mathrm{mM}$ Ethylenediaminetetraacetic Acid Disodium Salt ( $\mathrm{Na}_{2}$-EDTA), $100 \mathrm{mM}$ sodium phosphate, $1.5 \mathrm{M} \mathrm{NaCl}$, and $1 \%$ Cetrimonium bromide (CTAB)) and stored at $-80{ }^{\circ} \mathrm{C}$ until further processing. DNA extraction was performed following the EX DNA extraction protocol [37], and an exploration of the bacteria community was targeted using primers 27F ( $5^{\prime}$-AGA GTT TGA TCM TGG CTC AG-3') and 519R (5'-GWA TTA CCG CGG CKG CTG-3') [38,39], for the V3-V4 region of $16 \mathrm{~S}$ ribosomal RNA (rRNA) [40]. High-throughput sequencing was performed using the Illumina Miseq platform (Molecular Research LP; Shallowater, TX, USA) following the manufacturer's guidelines. Clustering analysis was performed on the sequence data using the Bray-Curtis distance and Ward's method [41] with the cluster package in R (version 1.14.3, R-studio). The relationship between the bacterial communities and the DOC was then assessed using redundancy analysis (RDA) in the CANOCO 5.0 software package [42] in BMs. 


\subsection{Preservation and Enumeration of HNFs, Phytoplankton, Ciliates, and Zooplankton}

For enumeration of the HNFs, a 10-mL sample was filtered onto a 1.0- $\mu \mathrm{m}$-pore Nuclepore filter (Japan KK, Tokyo, Japan) stained with Nigrosin, and the HNFs were stained with fluorescein isothiocyanate (FITC). The filters were observed under blue excitation (resulting in green fluorescence). One hundred HNFs were enumerated per sample. For phytoplankton, ciliate, and T. striata enumeration, a 1.0-L subsample was preserved with $0.5 \%$ Lugol's solution [43], concentrated to approximately $50 \mathrm{~mL}$ by decanting the supernatant [33] and counted using a Sedgewick-Rafter counting chamber (Rigosha Co., Tokyo, Japan) and light microscopy (Axioplan, Zeiss, Jena, Germany) at $400 \times$ magnification. Morphologically distinct phytoplankton cells were identified to species or genus level [44]. Zooplankton were sorted using a $60-\mu \mathrm{m}$-pore sieve from the 1-L subsample and collected into a 50-mL conical tube (SPL, Life Sciences, Pocheon, Korea) using filtered seawater. Zooplankton samples were subsequently preserved in $5 \%$ formalin, and individuals were counted using a zooplankton counting chamber under a dissecting microscope (Carl Zeiss, Jena, Germany) [45].

\subsection{Nutrients Analyses}

To analyze the concentration of inorganic nutrients, a 0.5-L subsample collected from each day was immediately filtered with a 47-mm-diameter GF/F filter (Whatman, Middlesex, U.K.) and placed in acid-cleaned polyethylene bottles. The filtered seawater was stored at $-20{ }^{\circ} \mathrm{C}$ in the dark until laboratory analysis. Ammonia $\left(\mathrm{NH}_{4}{ }^{+}\right)$, nitrate + nitrite $(\mathrm{NOx})$, phosphate $\left(\mathrm{PO}_{4}{ }^{3-}\right)$, and silicate $\left(\mathrm{Si}^{-}\right)$ concentrations $(\mu \mathrm{M})$ were determined in the laboratory using a flow injection autoanalyzer (QuikChem 8000; Lachat Instruments, Loveland, CO, USA). All nutrient concentrations were calibrated using standard brine solutions (CSK Standard Solutions; Wako Pure Chemical Industries, Osaka, Japan) with the detection limits of DIP $(0.02 \mu \mathrm{M})$, DIN $(0.05 \mu \mathrm{M})$, and DSi $(0.1 \mu \mathrm{M})$.

\section{Results}

\subsection{DOC and Bacteria in Cultivation Pond}

The dynamics of T. striata cell density and DOC concentration in the cultivation pond sampled are shown in Figure 3. The cell density of $T$. striata increased after initial inoculation of $T$. striata with the maximum cell density $\left(1.8 \times 10^{5}\right.$ cells $\left.\cdot \mathrm{mL}^{-1}\right)$ measured on day 5 , and then gradually decreased until day 9. The DOC concentration rapidly increased from day 2 with the maximum DOC concentration $\left(428.7 \mathrm{mg} \cdot \mathrm{L}^{-1}\right)$ measured on day 3 and then a gradual decrease until day 7 . The DOC concentration within the natural seawater also increased and decreased from day 2 to day 7 , but its maximum concentration $\left(24.7 \mathrm{mg} \cdot \mathrm{L}^{-1}\right)$ was significantly lower than that of the samples from the cultivation pond.

The bacterial community within the cultivation pond was substantially different to the natural seawater community (Figure 4). The Planctomycetaceae bacterial group dominated at day 0 and maintained its dominance $(29.4 \%)$ in natural seawater until day 9. On the other hand, the Rhodobacteraceae and Saprospiraceae dominated the cultivation pond on day 3 and day 9. The maximum percentage contributions of the Rhodobacteraceae group and Saprospiraceae group were $37.1 \%$ and $26.5 \%$, respectively, on day 3 in the cultivation pond. 


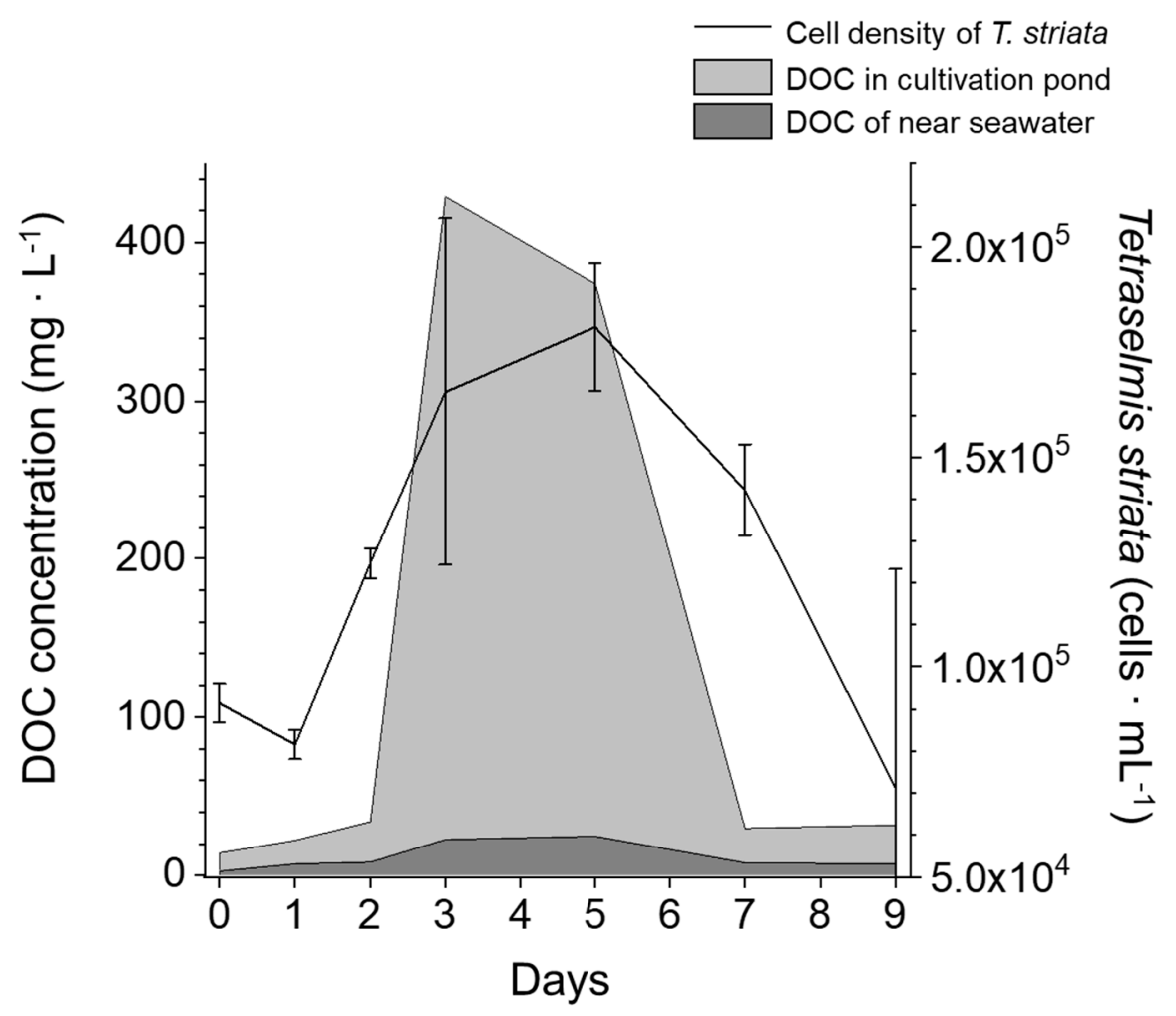

Figure 3. Dynamics of abundance of Tetraselmis striata cells cultured in cultivation pond, as well as concentrations of dissolved organic carbon (DOC) in cultivation pond and near ( $3 \mathrm{~m}$ away) seawater for nine days.

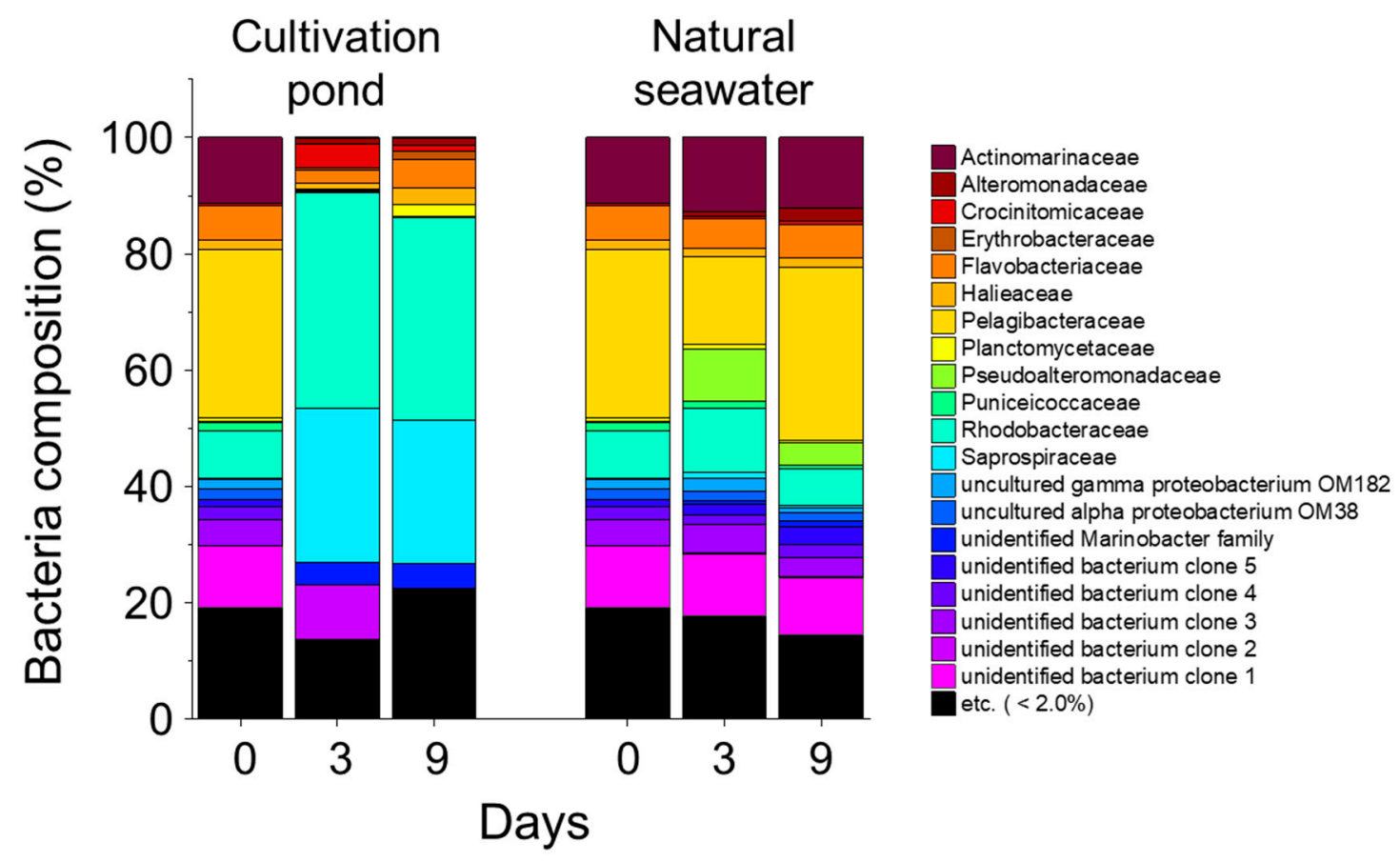

Figure 4. Changes in bacterial composition in cultivation pond and near ( $3 \mathrm{~m}$ away) seawater for nine days. 


\subsection{Environmental Factors during Mesocosm Experiment}

The seawater temperature gradually decreased from $22.0^{\circ} \mathrm{C}$ to $18.8^{\circ} \mathrm{C}$ during the mesocosm experiment (Figure 5A). Salinity gradually increased from 29.2 to 29.9 in the BMs and CMs, while salinity reached 30.7 on day 15 in the natural seawater (Figure 5B). The concentration of DO rapidly decreased after installation of the T. striata bioreactor starting at $0.47 \mathrm{mg} \cdot \mathrm{L}^{-1}$ on day 2 and remained low until the end of experiment (Figure 5C). The DO in the CMs, however, varied from 3.32 to $5.86 \mathrm{mg} \cdot \mathrm{L}^{-1}$, while the natural seawater varied from 5.35 to $7.89 \mathrm{mg} \cdot \mathrm{L}^{-1}$ (Figure 5C). Fluctuating patterns of DO in the BMs and natural seawater were similar (Figure $5 \mathrm{C}$ ). The $\mathrm{pH}$ of the BMs gradually decreased from 7.80 to 7.06 on day 9, although the low $\mathrm{pH}$ values of the CMs (7.40) and the natural seawater (7.50), as measured on day 9, were relatively high compared to the $\mathrm{BM} \mathrm{pH}$ of 7.12 (Figure 5D).
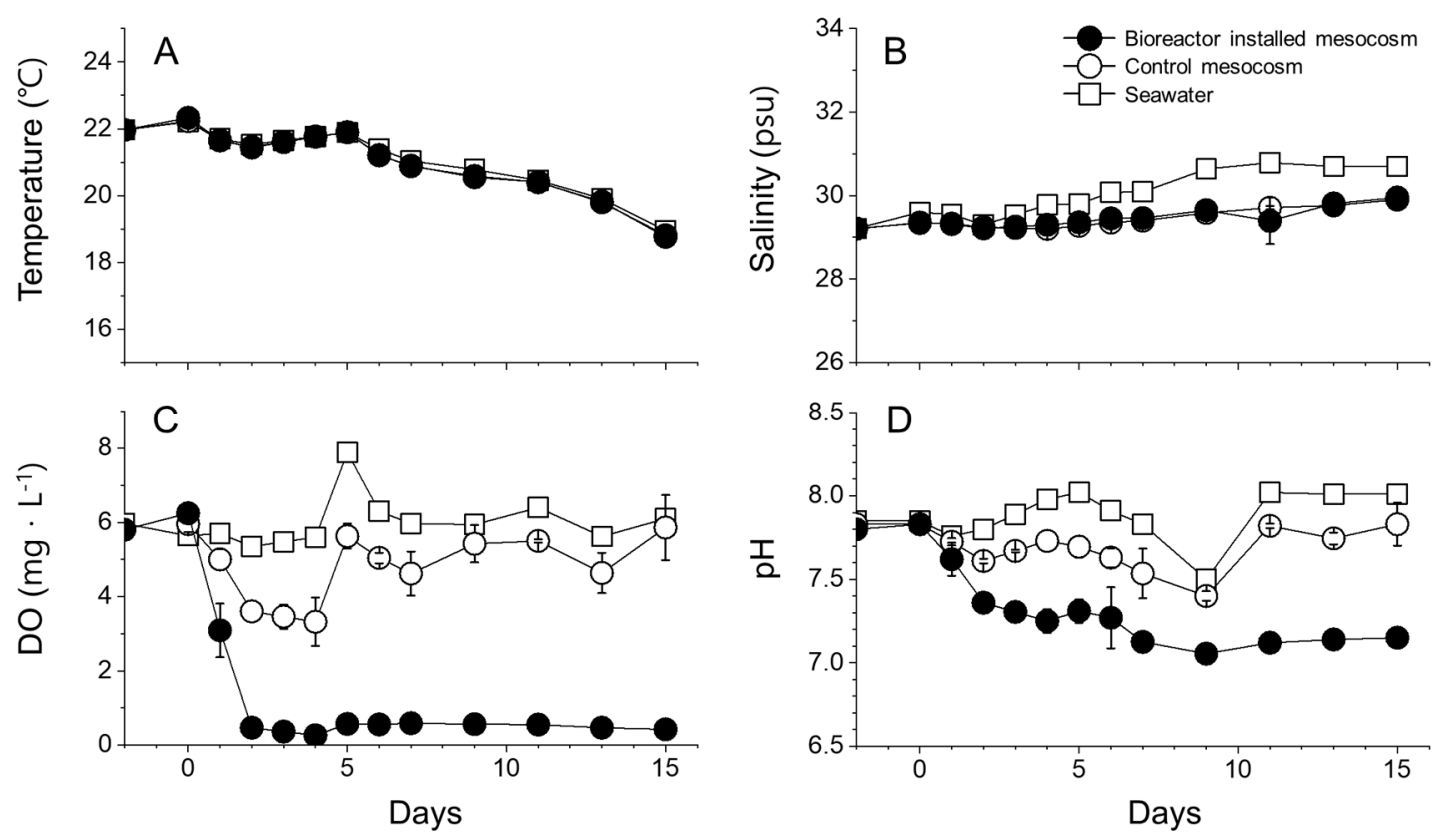

Figure 5. Changes in environmental factors: water temperature (A), salinity (B), dissolved oxygen (C), and $\mathrm{pH}$ (D) of each mesocosm and near seawater during mesocosm experiment period (15 days). Each value of white and dark circles was averaged using two measured values of the two bioreactor installed mesocosms or control mesocosms, respectively, but values of white squares were measured one time.

\subsection{Abundance of T. striata and DOC Concentration}

The initial mean cell density of T. striata in each bioreactor was $6343 \pm 696$ cells $\cdot \mathrm{mL}^{-1}$ at day 0 (Figure 6). Cell density then gradually increased on day 4 , then rapidly increased until day 6 (maximum cell density 149,550 $\pm 18,847$ cells $\cdot \mathrm{mL}^{-1}$ ). Cell abundance then rapidly decreased to $11,670 \pm 1232$ cells $\cdot \mathrm{mL}^{-1}$ on day 9 (Figure 6). The lowest cell density $\left(1250 \mathrm{cells} \cdot \mathrm{mL}^{-1}\right.$ ) was measured at the end of the mesocosm experiment on day 15 . The DOC concentration of natural seawater was $22.7 \mathrm{mg} \cdot \mathrm{L}^{-1}$ two days prior to the bioreactor installation, and it gradually decreased until day 0 for the CMs and day 1 for the BMs. The DOC concentration within the BMs gradually increased until day 4 , when it noticeably increased until day 6 (Figure 6). DOC then rapidly decreased to $6.74 \mathrm{mg} \cdot \mathrm{L}^{-1}$ in one day and maintained its low concentration until the end of the mesocosm period $\left(3.50 \mathrm{mg} \cdot \mathrm{L}^{-1}\right)$. The maximum DOC concentration within the BMs was $74.1 \mathrm{mg} \cdot \mathrm{L}^{-1}$ on day 6 . The DOC concentration with the CMs remained lower than that of BMs across the entire experiment, with its maximum concentration measured on day 13 as $5.38 \mathrm{mg} \cdot \mathrm{L}^{-1}$. The relative proportion of FLF was higher than the other fluorescence regions of DOC (PLF, HLF, and THLF) in both mesocosms (Figure 7). The proportion of FLF varied from $57.7 \%$ to $59.6 \%$ in the BMs and from $49.3 \%$ to $58.6 \%$ in the CMs. Increments and 
decrements of each relative proportion of the four DOC fractions were minor, but the change in the proportion of PLF was significantly $(p<0.05)$ correlated with a change in the total amount of DOC in the BMs (Figure 7). The maximum DOC concentration and the highest increment of PLF were measured on day 6 in the BMs.

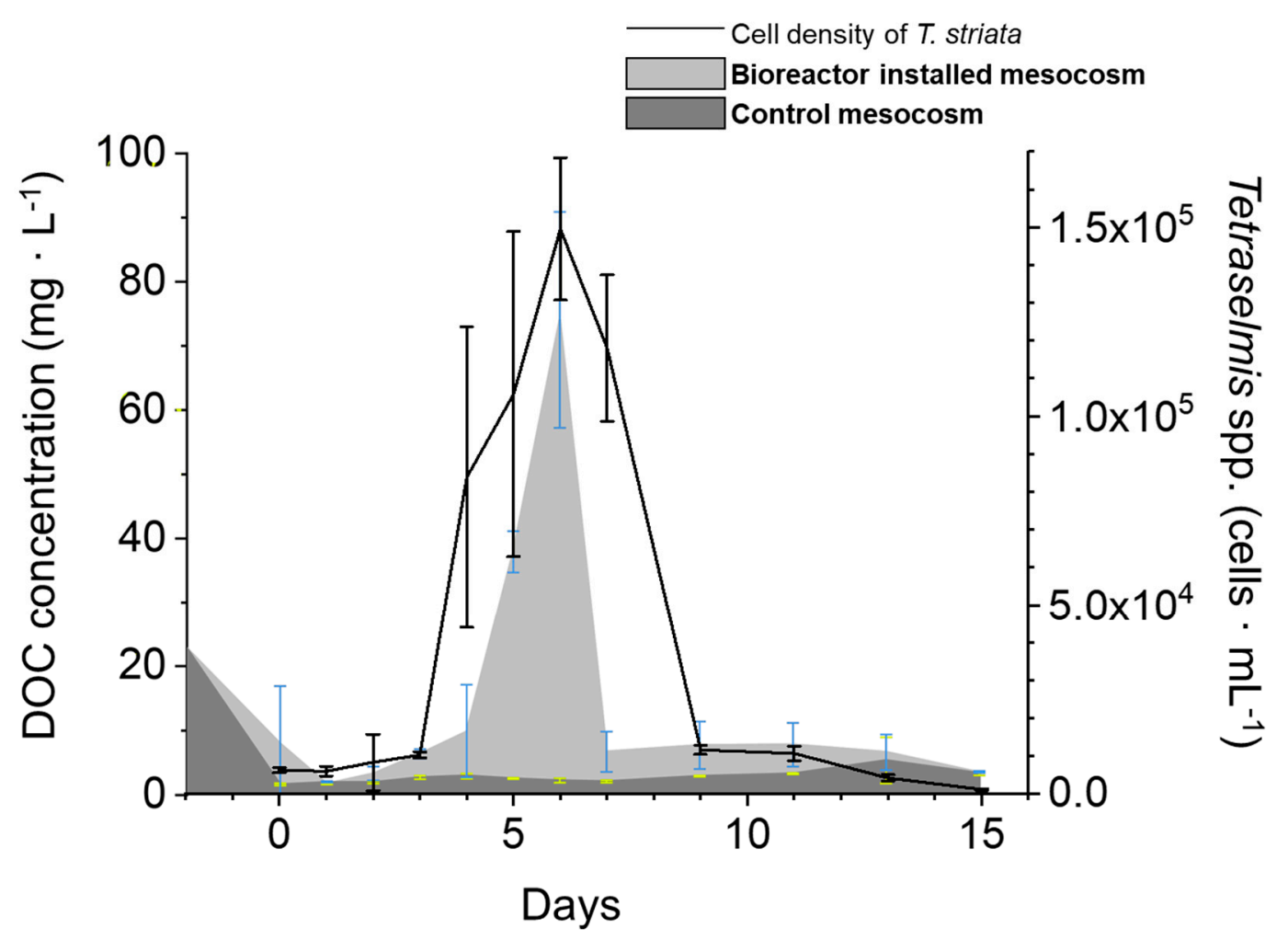

Figure 6. Dynamics of abundance of Tetraselmis striata cells cultured in bioreactors, and concentrations of dissolved organic carbon in bioreactor installed mesocosms and control mesocosms during mesocosm experiment period (15 days).

\begin{tabular}{|c|c|c|c|c|c|c|c|c|c|c|c|c|}
\hline \multirow{3}{*}{ Days } & \multicolumn{6}{|c|}{ Bioreactor of $T$. striata installed mesocosm } & \multicolumn{6}{|c|}{ Control mesocosm } \\
\hline & \multirow{2}{*}{$\begin{array}{c}\text { Total } \\
\operatorname{DOC}\left(\mathrm{mg} \cdot \mathrm{L}^{-1}\right)\end{array}$} & \multirow{2}{*}{$\begin{array}{l}\text { Ratios of PLF, FLF, } \\
\text { HLF and THLF (\%) }\end{array}$} & \multicolumn{4}{|c|}{ Changes of ratios $\left(\% \cdot\right.$ day $\left.^{-1}\right)$} & \multirow{2}{*}{$\begin{array}{c}\text { Total } \\
\text { DOC }\left(\mathrm{mg} \cdot \mathrm{L}^{-1}\right.\end{array}$} & \multirow{2}{*}{$\begin{array}{l}\text { Ratios of PLF, FLF, } \\
\text { HLF and THLF (\%) }\end{array}$} & \multicolumn{4}{|c|}{ Changes of ratios $\left(\% \cdot\right.$ day $\left.^{-1}\right)$} \\
\hline & & & $\mathrm{PLF}^{*}$ & FLF & HLF & THLF & & & PLF & FLF & HLF & THLF \\
\hline 1 & 1.8 & $6.5,58.5,16.1,18.9$ & 5.5 & -2.7 & 2.8 & 4.9 & 2.0 & $6.8,58.6,15.8,18.9$ & 8.4 & -0.7 & -3.8 & 3.0 \\
\hline 4 & 9.8 & $7.1,59.3,16.7,17.0$ & 2.2 & 0.3 & 0.9 & -2.5 & 3.0 & $6.4,52.2,17.2,24.2$ & -1.5 & -2.7 & 2.3 & 7.1 \\
\hline 5 & 37.9 & $7.3,59.6,16.3,16.8$ & 2.8 & 0.5 & -2.0 & -1.0 & 2.6 & $6.0,53.7,16.0,24.2$ & -5.4 & 2.9 & -7.3 & 0.3 \\
\hline 6 & 74.1 & $8.8,58.3,16.1,16.8$ & 21.3 & -2.2 & -1.5 & -0.2 & 2.3 & $6.2,49.7,16.6,27.5$ & 2.8 & -7.5 & 3.7 & 13.5 \\
\hline 9 & 7.7 & $7.7,58.9,16.2,17.2$ & -4.3 & 0.3 & 0.2 & 1.0 & 3.0 & $6.1,49.3,17.0,27.5$ & -0.4 & -0.3 & 0.9 & 0.0 \\
\hline 15 & 3.5 & $7.2,57.7,16.5,18.6$ & -1.0 & -0.3 & 0.3 & 1.3 & 3.4 & $6.2,52.3,17.0,24.4$ & 0.3 & 1.0 & 0.0 & -1.9 \\
\hline
\end{tabular}

Figure 7. Total concentrations of dissolved organic carbon (DOC) and relative ratios of four fractions of DOC (PLF, FLF, HLF and THLF), and its changes of each day in bio-reactor installed mesocosm and control mesocosm. Grey bars indicate the relative DOC concentrations, each ratio of orange, green, violet and yellow bar indicates the ratios of four fractions, respectively, and changed amounts of ratio of each four DOC fractions are indicated as blue (plus) and red (minus) bars, respectively.

\subsection{Bacterial Abundance and Composition}

The bacterial abundance within the BMs rapidly increased from day $0\left(2.24 \times 10^{6}\right.$ cells $\left.\cdot \mathrm{mL}^{-1}\right)$ to day $2\left(1.04 \times 10^{7}\right.$ cells $\left.\cdot \mathrm{mL}^{-1}\right)$ after the bioreactor installation. It then decreased until the end of the mesocosm experiment and finished on day 15 at $2.97 \times 10^{6}$ cells $\cdot \mathrm{mL}^{-1}$ (Figure $8 \mathrm{~A}$ ). The bacterial abundance within the CMs increased from day 1 to day 4 reaching $9.58 \times 10^{6}$ cells $\mathrm{mL}^{-1}$ (Figure $8 \mathrm{~A}$ ). At the end of the mesocosm experiment, the CMs contained a similar bacterial abundance $\left(1.09 \times 10^{7}\right.$ cells $\left.\cdot \mathrm{mL}^{-1}\right)$ compared to the BMs, but the highest abundance $\left(1.09 \times 10^{7}\right.$ cells $\left.\cdot \mathrm{mL}^{-1}\right)$ was reached on day 13 . Cluster 
analysis revealed five clades (A-E) of bacteria across all sampling days and both mesocosms (Figure 9). The bacteria grouped in the same clade (B) until day 0 , separated into two clades (D and E) on day 4 , and separated into another two clades ( $\mathrm{C}$ and $\mathrm{E}$ ) on day 9 . By day 15, the bacterial communities of BMs were separated into clade A alone.

In BMs, an Alteromonadaceae group dominated on day 1, but its proportion gradually decreased throughout the experiment. Alternatively, the Flavobacteriaceae and Oceanospirillaceae groups increased from day 4 to 9, a Cellvibrionaceae group increased from day 9, and a Rhodobacteraceae group gradually increased throughout the experiment. In the CMs, Alteromonadaceae and Oceanospirillaceae groups dominated at day 1 . The proportion of the Alteromonadaceae group decreased, but that of the Flavobacteriaceae group noticeably increased from days 4 to 6 (Figure 9). The proportions of ect. bacterial groups $(<2 \%)$, which dominated two days prior to the beginning of the experiment and rapidly decreased in both mesocosms, but increased again in the CMs from days 9 to 15 . At the end of mesocosm experiment, the Shannon diversity index decreased to 4.8 and 4.1 in each BM, but relatively higher diversities (6.0) were observed in the CMs compared to the BMs. ANOVA analysis revealed that the bacterial diversity of clade A (day 15 of BMs) was significantly $(p<0.05)$ lower than that of clades B and C.
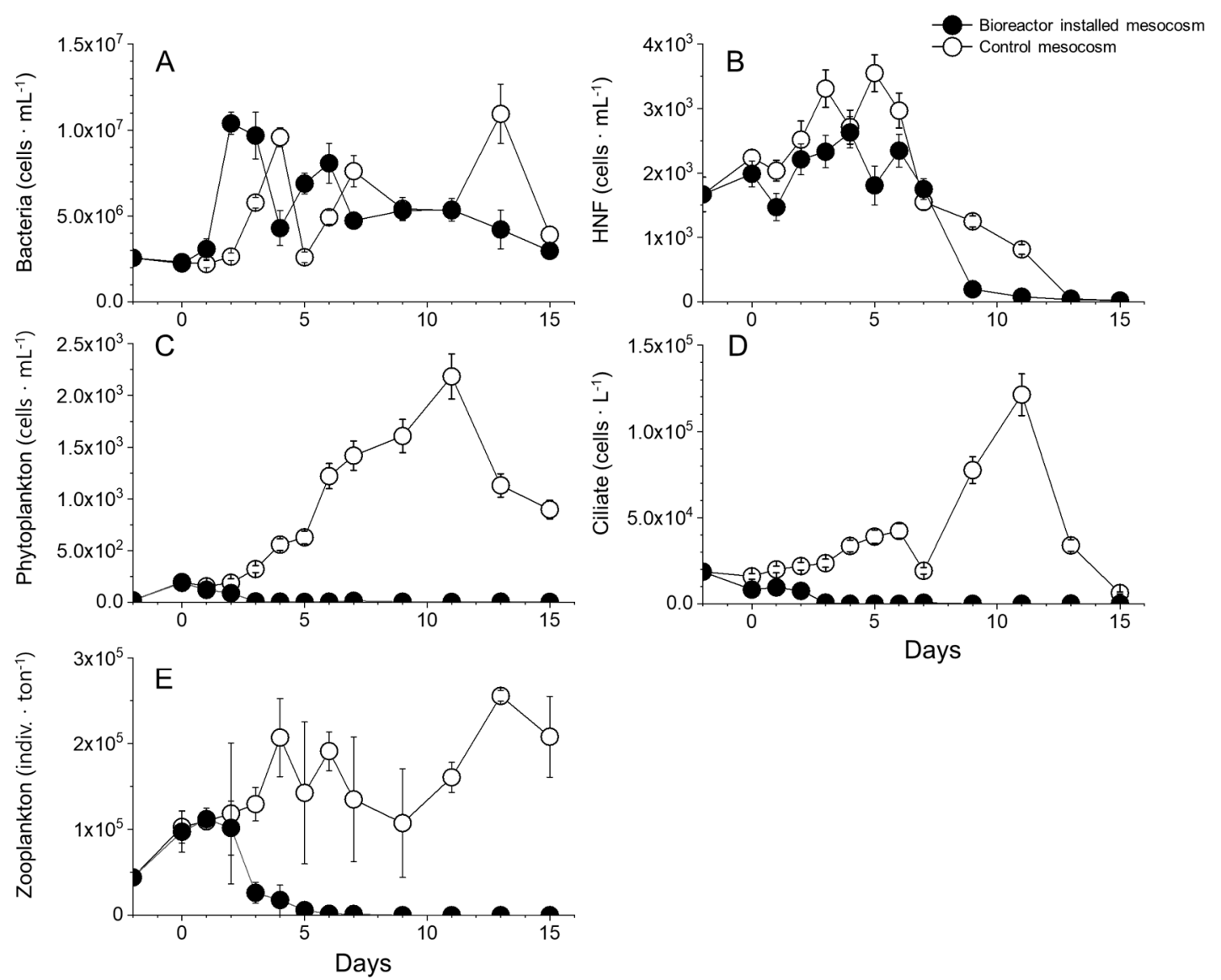

Figure 8. Dynamics of abundance of biotic factors: bacteria (A), heterotrophic nano-flagellates (B), phytoplankton (C), ciliate (D), and zooplankton (E) during mesocosm experiment period (15 days). Each value of white and dark circles was averaged using two measured values of bioreactor installed mesocosms or control mesocosms, respectively. 


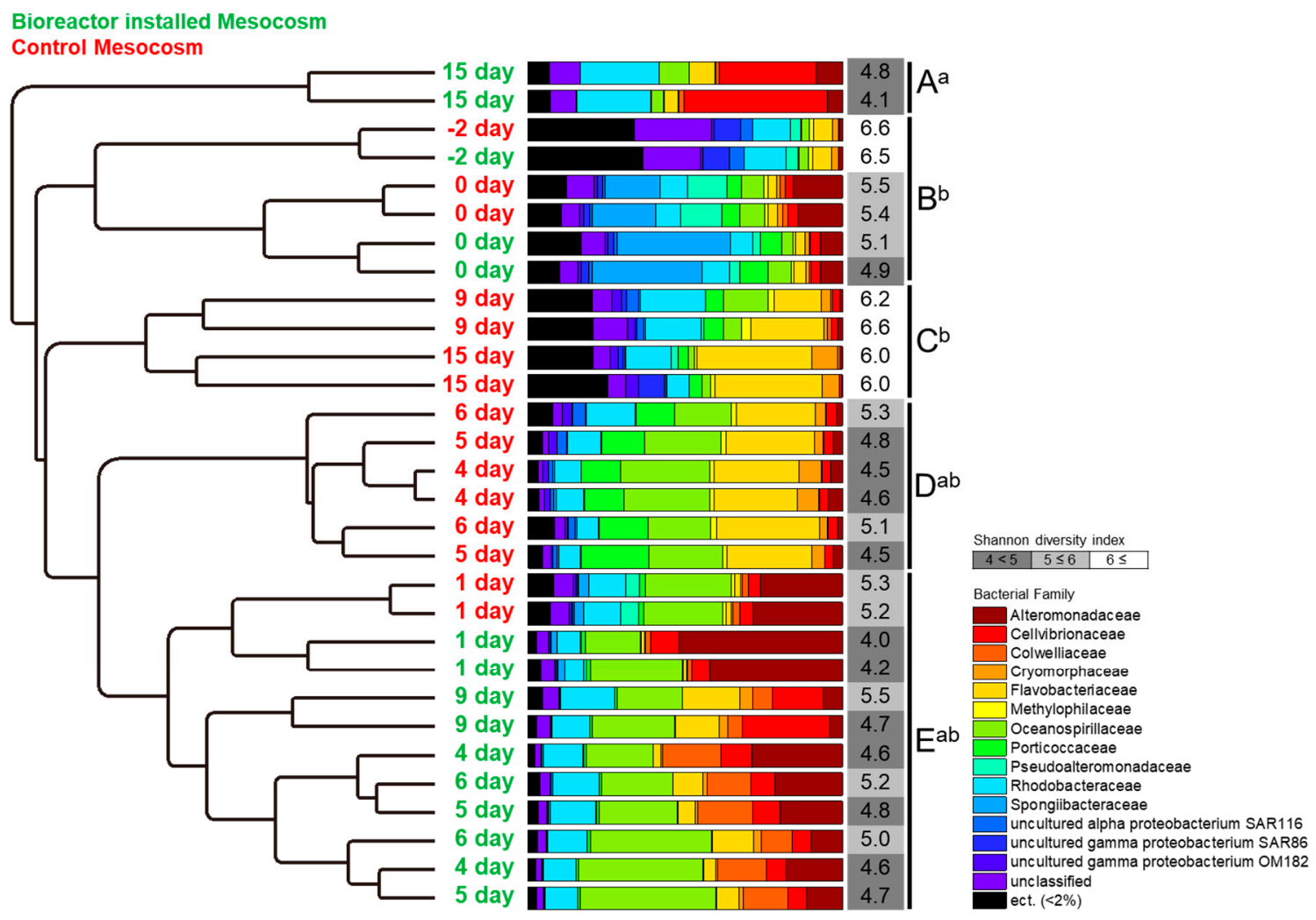

bray_curtis Distance

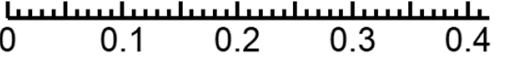

Figure 9. Cluster analysis using Ward's method for the Bray-Curtis distance for bacterial community structure and the Shannon diversity index of each mesocosm for 15 experimental days. Each component of the clades is marked with green and red colors for the bioreactor installed mesocosm and control mesocosm, respectively. The five clades (A-E) were divided into three groups $a, b$, and $a b$, according to the average Shannon diversity index of each clade by analysis of variance (ANOVA).

\subsection{Relationship between Bacterial Community and DOC}

The RDA showed a significant relationship $(p<0.05)$ between the amount of DOC and relative amounts of the four DOC fractions, as well as the occurrence of family-level bacterial groups in the BMs (Figure 10). The concentration of DOC was strongly correlated to T. striata cell density and the Colwelliacae group. The concentration of PLF also showed a strong relationship with two distinct bacterial groups-the Rhodobacteraceae and the Flavobacteriaceae. RDA revealed that the majority of the variance was explained by axis $1(66.9 \%)$ and axis $2(22.2 \%)$.

\subsection{Other Biotic Factors}

The increasing and decreasing patterns of HNFs in both mesocosms were similar, but the CMs showed higher HNF abundances than those within the BMs (Figure 8B). The maximum abundance of $\mathrm{HNF}$ in the CMs was 3551 cells $\cdot \mathrm{mL}^{-1}$ on day 5 and $2630 \mathrm{cells} \cdot \mathrm{mL}^{-1}$ on day 4 for the BMs. The abundances of HNFs in both mesocosms rapidly decreased from day 7 until a final abundance of 21 (BMs) and $22(\mathrm{CMs})$ cells $\cdot \mathrm{mL}^{-1}$ at the end of the mesocosm experiment (Figure $8 \mathrm{~B}$ ). The CM phytoplankton abundance gradually increased from day 1 until its highest abundance on day $11\left(2185 \mathrm{cells} \cdot \mathrm{mL}^{-1}\right)$ (Figure 8C). On the other hand, the phytoplankton within the BMs gradually decreased from day 1 , and very few phytoplankton cells were observed from day 3 to the end of the mesocosm experiment (Figure 8C). The most abundant species throughout the experiment within the CMs was Chaetoceros spp. (data not shown). The abundance patterns of ciliates within both mesocosms were similar to 
those of phytoplankton (Figure 8D). The maximum ciliate abundance within the CMs was recorded as $1.21 \times 10^{5}$ cells $\cdot \mathrm{mL}^{-1}$ on day 11 , but that in the BMs decreased from day 1 , with most dead by day 3 (Figure $8 \mathrm{D}$ ). Zooplankton abundance in both mesocosms was similar until day 2, whereby the abundance in the BMs rapidly decreased from day 2, with none observed by day 9 (Figure 8E). In the case of the CMs, zooplankton were observed until day 9 and then rapidly increased from then until day

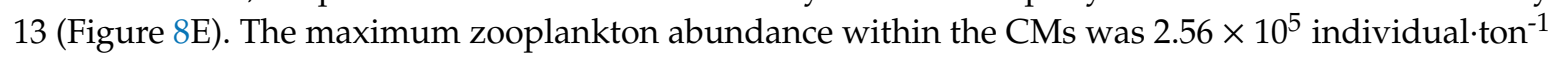
on day 13.

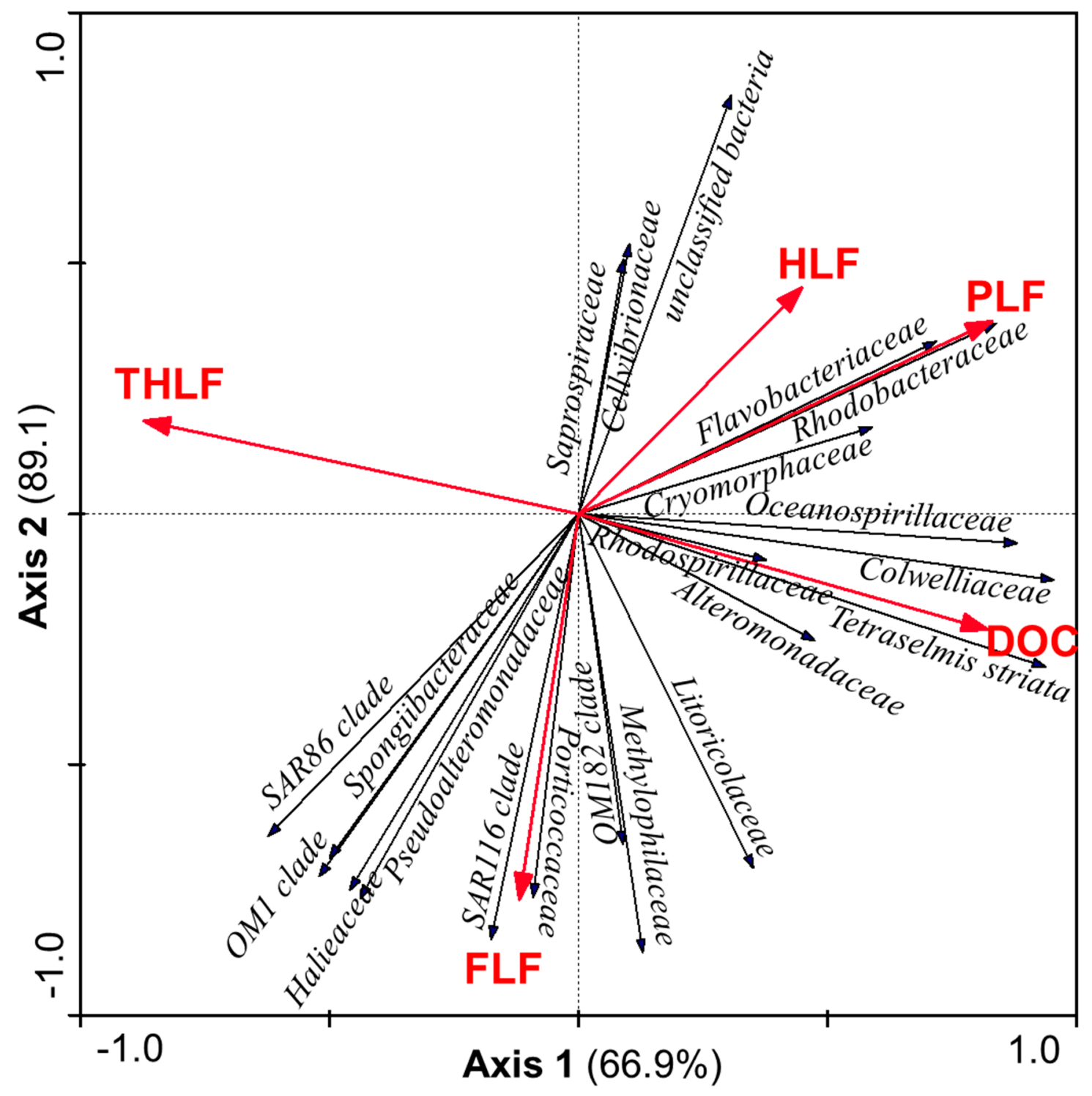

Figure 10. The redundancy analysis to determine the relationship between dissolved organic carbon (DOC) including four different fractions (PLF, protein-like fluorescence; FLF, fulvic-like fluorescence; HLF, humic-like fluorescence; THLF, terrestrial humic-like fluorescence) and bacterial groups at the family level.

\subsection{Nutrient Dynamics}

Concentrations of inorganic nutrient in the surrounding seawater two days prior to the mesocosm experiment were $12.7 \mu \mathrm{M}$ for NOx, $9.6 \mu \mathrm{M}$ for ammonium, $1.1 \mu \mathrm{M}$ for phosphate, and $32.8 \mu \mathrm{M}$ for silicate (Figure 11). Concentrations of $\mathrm{NO}_{x}$ and phosphate then increased on day 0 to 40.1 (BMs) and $41.7 \mu \mathrm{M}(\mathrm{CMs})$ for $\mathrm{NO}_{\mathrm{x}}$, and $2.5(\mathrm{BMs})$ and $2.7 \mu \mathrm{M}(\mathrm{CMs})$ for phosphate, due to the additional inoculations of $\mathrm{NaNO}_{3}$ and $\mathrm{NaH}_{2} \mathrm{PO}_{4}$ (Figure 11A,C). Except for the silicate within the BMs, 
the concentrations of nutrients gradually decreased during the mesocosm period, but decreased more rapidly in the BMs as compared to the CMs (Figure 11A,C). The patterns of ammonium concentrations of both mesocosms were similar throughout the experiment (Figure 11B). The concentration of silicate within the BMs remained steady, but rapidly decreased from day 7 within the CMs (Figure 11D).
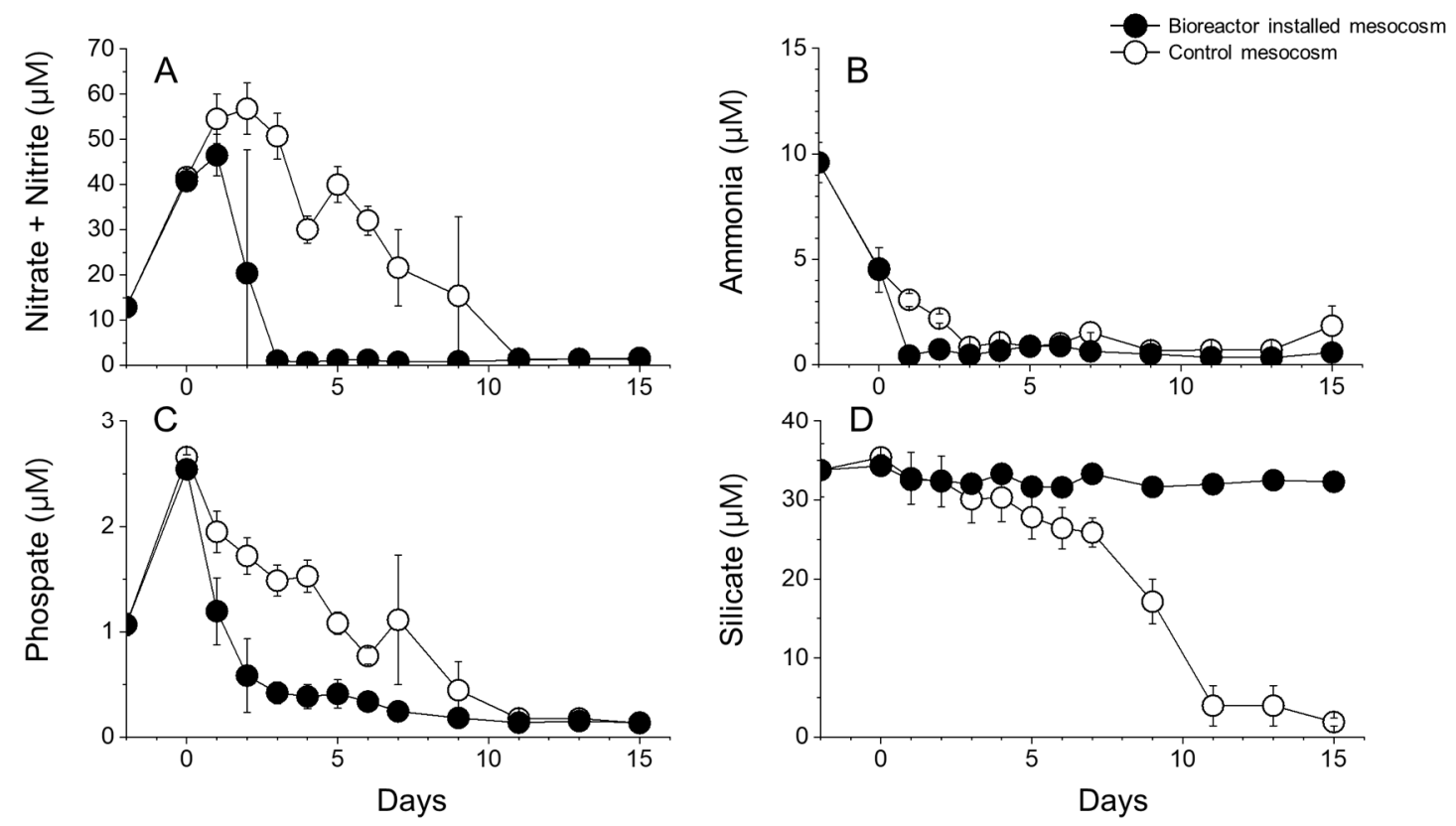

Figure 11. Changes in inorganic nutrient concentrations: nitrate + nitrite (A), ammonium (B), phosphate (C), and silicate (D) during mesocosm experiment period (15 days). Each value of white and dark circles was averaged by two measured values of bioreactor installed mesocosms or control mesocosms, respectively.

\section{Discussion}

\subsection{DOC Released from T. striata}

Dissolved organic carbon (DOC) in the ocean is one of the largest carbon pools on Earth [46]. The extracellular release of recently fixed photosynthate is the major DOC production process in the marine ecosystem [47]. Our study revealed significant correlations between the cell density of T. striata and DOC concentration in both the cultivation pond and the mesocosm experiments. When the growth rate of T. striata was high, the amount of DOC secreted was high. The highest $T$. striata cell densities were observed on day 5 (cultivation pond) and day 6 (mesocosms). Although the high cell densities were still observed on day 7 in both the cultivation pond and the mesocosms, the DOC concentrations rapidly decreased. Phytoplankton usually sequester excess carbon in the form of storage polysaccharides, such as chrysolaminarin in diatoms [48,49] and glycogen in cyanobacteria [50]. These polymers also constitute the main fraction of phytoplankton exudates. According to Aluwihare and Repeta (1999), up to $37 \%$ of the DOC originating from phytoplankton consists of high-molecular-weight $(>1 \mathrm{kDa})$ components, mainly hydrolyzable carbohydrates. The polysaccharides represent the largest fraction of high-molecular-weight DOC, with around 50\% relative amount of the DOC in surface waters and around 25\% in deep waters [51]. Various studies from the North Atlantic also support this large polysaccharide component with samples from the North Atlantic $(<11 \%$ of total DOC) [52], the Norwegian Sea $(<14.8 \%)$ [53], and the North Pacific $(<10.1 \%)$ [54].

In aquatic systems, bottom-up (inorganic and organic nutrient supply) factors significantly influence bacterial succession. The DOC in marine ecosystems is almost completely cycled by bacterial groups over different timescales depending on different biochemical characteristics of the water column. The DOC pool constitutes the so-called "labile" fraction and turns over rapidly (hours to days). 
The "semi-labile" fraction is cycled by bacteria on time scales of weeks to months [55], while the so called "refractory" DOC pool is biologically cycled on time scales ranging from centuries to millennia $[55,56]$. Therefore, in order to understand the close variation of the bacterial community, it is necessary to examine the differing fractions of DOC. Hur et al. (2011) [35] proposed that the methodology of DOC be divided into four fractions to characterize the DOC depending on the varying biological component, as well as temporal and differing regional sources. In addition, the proportion of PLF measured from phytoplankton was higher (73.9\%) than the other organic matters (leaf litter, compost, and paddy water) in their experiment. In our study, a high concentration of DOC $\left(74.1 \mathrm{mg} \cdot \mathrm{L}^{-1}\right)$ and a significant correlation between the amount of DOC released from T. striata and the proportion of PLF was observed in our mesocosm study; however, the PLF fraction was relatively lower than the other DOC fractions during the mesocosm experiment. Although the amount of PLF fraction was small, its changes were significantly correlated with the total amount of DOC and biomass of T. striata. This may be explained by the fact that the release of compounds from phytoplankton is susceptible to rapid uptake by heterotrophic bacteria [57]. This microbial degradation can induce the dramatic decrease of PLF and the enhancement of the FLF, the HLF, and the THLF fractions at the same DOC concentration [35].

\subsection{Changes in Bacterial Community in Cultivation Pond and Mesocosms}

The bacterial community within the cultivation pond was significantly different to that observed in the natural seawater during our experiment. A noticeable increase in the ratio of Rhodobacteraceae was recorded; however, these results do not consider the attached and/or free-living bacteria. It is, therefore, difficult to determine the direct effect of DOC released from $T$. striata on the bacterial community as a whole. The T. striata strain employed in our experiments was axenic, which may have introduced bacteria into the cultivation pond upon inoculation. It is difficult to be certain, therefore, whether a large proportion of the Rhodobacteraceae and Saprospiraceae bacterial groups was present at the time of inoculation or naturally increased, but the bacterial species diversity certainly decreased over the experimental duration. Despite the experimental set-up being a "semi-natural" condition, results from the mesocosm experiment suggest that there was an effect on the bacterial community from the DOC release. Evidence to support this include the following: the bacterial compositions of CMs and BMs were clearly differentiated at the end of the experiment, with a significantly decreased bacterial species diversity; the initial bacterial diversity in both mesocosms and the CMs on day 15 were high, but the diversity of the BMs on day 15 was significantly $(p<0.05)$ lower; in the BMs, the Cellvibrionaceae group occupied a large proportion, while the uncultured alpha and gamma Proteobacterium and etc. groups noticeably decreased at the end of mesocosm experiment (Figure 9). An increase in bacterial groups which favor the DOC artificially increased by the large cultivation of $T$. striata would have resulted in a reduction of the natural bacterial group.

The Rhodobacteraceae group increased in the T. striata cultivation pond. Interestingly, this bacterial group also gradually increased in the mesocosm experiment after the installation of the T. striata bioreactor. The most relevant bacterial group was the Rhodobacteraceae for the PLF fraction in the analysis, followed by the Flavobacteriaceae (Figure 10). Many previous studies reported that the Rhodobacteraceae group is closely correlated with phytoplankton blooms, for example, blooms of Akashiwo sanguinea, Alexandrium spp., Gymnodinium catenatum, Karenia mikimotoi, Prorocentrum lima, and Leptocylindrus spp. [58-64]. Interestingly, most of the Rhodobacteraceae bacteria (90\%) contain the vitamin B12 synthesis pathway, which is suggested to help in the growth of phytoplankton [65]. Furthermore, the Flavobacteriaceae are chemo-organotrophic [66,67], and strains were shown to synthesize proteins that actively bind and exploit algal polymeric substrates, such as carbohydrates, polypeptides, and lipids [68]. This bacterial group can be a dominant group in particle-attached communities [69] and are also closely associated with phytoplankton blooms [59,70]. Another bacterial group, the Colwelliaceae, although not strongly correlated with the PLF fraction in our study, is highly associated with the total amount of DOC. The genus Colwellia, the type genus in the Colwelliaceae, 
only found in oceanic environments, is known as polysaccharide-degrading bacteria [71]. It is also a classic marine secondary producer and a key player in the global carbon cycle. Colwelliaceae are involved in decomposing organic material such as hydrocarbons, lipids, proteins, and polysaccharides within particulates of the pelagic zone and sea ice, and within algal, faunal, and floral associations, where it engaged in anaerobic respiration and/or fermenting [72]. The Rhodobacteraceae and Flavobacteriaceae groups, therefore, seem to be related to the growth of T. striata, and the Colwelliaceae group seems to be related to the degradation or termination of $T$. striata or the other phytoplankton cells in the BMs. Specific bacterial-algal associations are not cultural artificial effects, but relevant and important relationships in natural field populations. Further investigations into the specific functions of bacterial and algal metabolites, as well as transcriptomic studies, could provide a clue to the clarification of the relationship between these bacteria and phytoplankton groups.

\subsection{Microbial Food Web Structure}

Installed mesocosms maintained an environment similar to the natural condition during experiments. There was little difference between the surrounding water temperature and salinity compared to that measured within the mesocosms. The $\mathrm{DO}$ and $\mathrm{pH}$, however, varied slightly between the natural seawater and the mesocosms, but the pattern of these variables over time remained the same in each. The abrupt dissipation of phytoplankton communities could lead to a decrease in DO and $\mathrm{pH}$ in the BMs. The major differences in biological factors between the CMs and BMs was the abrupt decrease in the abundance of phytoplankton, followed by the ciliate and zooplankton of the BMs. The abundance of phytoplankton began to decrease on day 1 of $T$. striata cultivation, while the ciliates began to decrease over the following two days and the zooplankton over the following three days. The initial decrease in phytoplankton coincided with a rapid decrease in $n$ and $p$ after T. striata inoculation. Especially, the mechanism of "luxury uptake" is known to occur when phytoplankton including Tetraselmis rapidly uptake and store excess phosphorus as inorganic polyphosphate granules [73-76]. In contrast, silicate rapidly decreased in the CMs after day 3 due to the dominance of the diatom Chaetoceros spp. Since inorganic nutrients are continuously supplied in natural marine environments, it is difficult to partition the rapid nutrient uptake of T. striata and its effect on the growth of other phytoplankton. Another possible influence on phytoplankton growth/succession patterns could be due to allelopathy and algicidal bacteria. Although this was not the focus of the present study, it is known that many phytoplankton species are able to secrete an allelopathic substance that can inhibit the growth of other organisms [77]. A rapid increase in DOC was associated with the growth of T. striata, and the possibility of the presence of a large amount of allelopathic material could be a possibility to explain this increase. On day 1 when growth of phytoplankton began to decrease, the proportion of the Alteromonadaceae bacterial group increased noticeably. The dominant genus group was Alteromonas. Many species of Alteromonas show an algicidal effect on various phytoplankton communities such as dinoflagellate, raphidophyte, and diatom, even working on phytoplankton species of freshwater [78-83].

The decrease in phytoplankton was followed by a decrease in the population of zooplankton and ciliates, which are higher trophic levels in nature. There may, however, be an alternate reason in our study. The cultivation of T. striata using semi-permeable membranes may have physically inhibited the transfer of energy from phytoplankton to higher trophic levels. Bacterial-sized organisms are able to migrate, but the semi-permeable membrane obstructed the direct interaction of phytoplankton (T. striata) with ciliates and zooplankton, such that activities including feeding and decomposition were disabled. This may have resulted in an imbalanced trophic structure within the BMs, whereby the higher trophic levels were removed (or extremely reduced).

\section{Conclusions}

Our novel work demonstrates that large amounts of DOC secreted by large-scale microalgal cultures such as that of $T$. striata can potentially have a significant impact on the structure and function of the surrounding microbial ecosystem. From our experimental results, DOC released from the 
cultivation of T. striata led to (i) changes in bacterial communities, (ii) disturbance of the microbial food web and trophic structure, and (iii) a rapid depletion of nutrients and a decrease in $\mathrm{DO}$ and $\mathrm{pH}$. An opened or semi-opened mesocosm is needed to better reflect the natural ecosystem, and a steady monitoring study around the marine culturing field should be done in parallel. In addition, more detailed molecular analysis is required to understand the interaction between specific phytoplankton with the surrounding bacterial community. Recent "omics" approaches allow for better insight into the mutual interactions between phytoplankton and heterotrophic bacteria, with metagenomes revealing partnerships and transcripts that resolve the different physiological processes executed by the different partners. Proteomes may further reveal species-specific exudates in multispecies assemblages, as well as the response to the presence of specific bacteria.

Author Contributions: Conceptualization, S.-H.K., J.H.K., S.H.B., B.S.P., and M.-S.H.; Methodology, S.-H.K., J.H.K., S.H.B., J.-H.K., B.S.P., and M.-S.H.; Investigation, S.-H.K., J.H.K., and S.H.B.; Resources, S.H.B., and M.-S.H.; Supervision, B.S.P., and M.-S.H.; Visualization, S.-H.K., and J.H.K. Writing-original draft, J.H.K.; Writing-review and editing, S.-H.K., J.H.K., P.A.A., B.S.P., and M.-S.H.; Funding acquisition, B.S.P., and M.-S.H. All authors have read and agreed to the published version of the manuscript.

Funding: This research was supported by the National Research Foundation of Korea (NRF) grant funded by the Korea government (MSIT) (NRF-2020R1C1C1011466), grant from the Korea Institute of Ocean Science and Technology (PE99821) and Marine Biotechnology Program [grant number PJT200255, Development of Marine Microalgal Biofuel Production Technology) funded by the Ministry of Oceans and Fisheries, Korea.

Conflicts of Interest: The authors declare no conflict of interest.

\section{References}

1. Nashawi, I.S.; Malallah, A.; Al-Bisharah, M. Forecasting world crude oil production using multicyclic Hubbert model. Energy Fuels 2010, 24, 1788-1800. [CrossRef]

2. Wijffels, R.H.; Barbosa, M.J. An outlook on microalgal biofuels. Science 2010, 329, 796-799. [CrossRef] [PubMed]

3. Amaro, H.M.; Guedes, A.C.; Malcata, F.X. Advances and perspectives in using microalgae to produce biodiesel. Appl. Energy 2011, 88, 3402-3410. [CrossRef]

4. Chisti, Y. Biodiesel from microalgae. Biotechnol. Adv. 2007, 25, 294-306. [CrossRef] [PubMed]

5. Patidar, S.K.; Kim, S.-H.; Kim, J.H.; Park, J.; Park, B.S.; Han, M.-S. Pelagibaca bermudensis promotes biofuel competence of Tetraselmis striata in a broad range of abiotic stressors: Dynamics of quorum-sensing precursors and strategic improvement in lipid productivity. Biotechnol. Biofuels 2018, 11, 102. [CrossRef]

6. Danquah, M.; Harun, R.; Halim, R.; Forde, G. Cultivation medium design via elemental balancing for Tetraselmis suecica. Chem. Biochem. Eng. Q. 2010, 24, 361-369.

7. Huang, X.; Huang, Z.; Wen, W.; Yan, J. Effects of nitrogen supplementation of the culture medium on the growth, total lipid content and fatty acid profiles of three microalgae (Tetraselmis subcordiformis, Nannochloropsis oculata and Pavlova viridis). J. Appl. Phycol. 2013, 25, 129-137. [CrossRef]

8. Moheimani, N.R. Inorganic carbon and $\mathrm{pH}$ effect on growth and lipid productivity of Tetraselmis suecica and Chlorella sp (Chlorophyta) grown outdoors in bag photobioreactors. J. Appl. Phycol. 2013, 25, 387-398. [CrossRef]

9. Kim, G.; Bae, J.; Lee, K. Nitrate repletion strategy for enhancing lipid production from marine microalga Tetraselmis sp. Bioresour. Technol. 2016, 205, 274-279. [CrossRef]

10. Selvakumar, P.; Umadevi, K. Enhanced lipid and fatty acid content under photoheterotrophic condition in the mass cultures of Tetraselmis gracilis and Platymonas convolutae. Algal Res. 2014, 6, 180-185. [CrossRef]

11. Teo, C.L.; Atta, M.; Bukhari, A.; Taisir, M.; Yusuf, A.M.; Idris, A. Enhancing growth and lipid production of marine microalgae for biodiesel production via the use of different LED wavelengths. Bioresour. Technol. 2014, 162, 38-44. [CrossRef] [PubMed]

12. Úbeda-Mínguez, P.; Chileh, T.; Dautor, Y.; García-Maroto, F.; Alonso, D.L. Tools for microalgal biotechnology: Development of an optimized transformation method for an industrially promising microalga-Tetraselmis chuii. J. Appl. Phycol. 2015, 27, 223-232. [CrossRef]

13. Vuttipongchaikij, S. Genetic manipulation of microalgae for improvement of biodiesel production. Genom. Genet. 2012, 5, 130-148. 
14. Kim, Z.-H.; Park, H.; Lee, C.-G. Seasonal assessment of biomass and fatty acid productivity by Tetraselmis sp. in the ocean using semi-permeable membrane photobioreactors. J. Microbiol. Biotechnol. 2016, 26, 1098-1102. [CrossRef] [PubMed]

15. Kim, Z.-H.; Park, H.; Ryu, Y.-J.; Shin, D.-W.; Hong, S.-J.; Tran, H.-L.; Lim, S.-M.; Lee, C.-G. Algal biomass and biodiesel production by utilizing the nutrients dissolved in seawater using semi-permeable membrane photobioreactors. J. Appl. Phycol. 2015, 27, 1763-1773. [CrossRef]

16. Jiang, Y.; Chen, F. Effects of temperature and temperature shift on docosahexaenoic acid production by the marine microalge Crypthecodinium cohnii. J. Am. Oil Chem. Soc. 2000, 77, 613-617. [CrossRef]

17. Jorquera, O.; Kiperstok, A.; Sales, E.A.; Embirucu, M.; Ghirardi, M.L. Comparative energy life-cycle analyses of microalgal biomass production in open ponds and photobioreactors. Bioresour. Technol. 2010, 101, 1406-1413. [CrossRef]

18. Wang, J.; Sommerfeld, M.R.; Lu, C.; Hu, Q. Combined effect of initial biomass density and nitrogen concentration on growth and astaxanthin production of Haematococcus pluvialis (Chlorophyta) in outdoor cultivation. Algae 2013, 28, 193-202. [CrossRef]

19. Zhu, L.; Hiltunen, E.; Antila, E.; Zhong, J.; Yuan, Z.; Wang, Z. Microalgal biofuels: Flexible bioenergies for sustainable development. Renew. Sustain. Energy Rev. 2014, 30, 1035-1046. [CrossRef]

20. Broome, S.; Craft, C.; Struck, S.; San Clements, M. Effects of Shading from Bridges on Estuarine Wetlands; Final Report; US Department of Transportation Research and Special Programs Administration: NC, USA, 2005. Available online: http://www.ncdot.gov/doh/preconstruct/tpb/research/download/2001-12finalreport.pdf (accessed on June 2019).

21. Kennish, M.J.; Haag, S.M.; Sakowicz, G.P. Seagrass demographic and spatial habitat characterization in Little Egg Harbor, New Jersey, using fixed transects. J. Coast. Res. 2008, 55, 148-170. [CrossRef]

22. Seiyaboh, E.; Inyang, I.; Gijo, A. Environmental impact of Tombia bridge construction across Nun river in central Niger delta, Nigeria. Int. J. Eng. Sci. 2013, 2, 32-41.

23. Livanou, E.; Lagaria, A.; Psarra, S.; Lika, K. A DEB-based approach of modeling dissolved organic matter release by phytoplankton. J. Sea Res. 2019, 143, 140-151. [CrossRef]

24. Thomas, J.P. Release of dissolved organic matter from natural populations of marine phytoplankton. Mar. Biol. 1971, 11, 311-323. [CrossRef]

25. Thornton, D.C. Dissolved organic matter (DOM) release by phytoplankton in the contemporary and future ocean. Eur. J. Phycol. 2014, 49, 20-46. [CrossRef]

26. Crump, B.C.; Kling, G.W.; Bahr, M.; Hobbie, J.E. Bacterioplankton community shifts in an arctic lake correlate with seasonal changes in organic matter source. Appl. Environ. Microbiol. 2003, 69, 2253-2268. [CrossRef]

27. Eiler, A.; Langenheder, S.; Bertilsson, S.; Tranvik, L.J. Heterotrophic bacterial growth efficiency and community structure at different natural organic carbon concentrations. Appl. Environ. Microbiol. 2003, 69, 3701-3709. [CrossRef]

28. Park, J.; Park, B.S.; Wang, P.; Patidar, S.K.; Kim, J.H.; Kim, S.-H.; Han, M.-S. Phycospheric native bacteria Pelagibaca bermudensis and Stappia sp. ameliorate biomass productivity of Tetraselmis striata (KCTC1432BP) in co-cultivation system through mutualistic interaction. Front. Plant Sci. 2017, 8, 289. [CrossRef]

29. Buchan, A.; LeCleir, G.R.; Gulvik, C.A.; González, J.M. Master recyclers: Features and functions of bacteria associated with phytoplankton blooms. Nat. Rev. Microbiol. 2014, 12, 686. [CrossRef]

30. Ederington, M.C.; McManus, G.B.; Harvey, H.R. Trophic transfer of fatty acids, sterols, and a triterpenoid alcohol between bacteria, a ciliate, and the copepod Acartia tonsa. Limnol. Oceanogr. 1995, 40, 860-867. [CrossRef]

31. Wang, P.; Joo, J.-H.; Park, B.S.; Kim, J.-H.; Kim, J.H.; Han, M.-S. Relationship between dissolved organic carbon and bacterial community in the coastal waters of Incheon, Korea. Oceanol. Hydrobiol. Stud. 2017, 46, 50-61. [CrossRef]

32. Guillard, R.R. Culture of Phytoplankton for Feeding Marine Invertebrates, Culture of Marine Invertebrate Animals; Springer: Berlin, Germany, 1975; pp. 29-60.

33. Sournia, A. Phytoplankton, manual. In Monographs on Oceanographic Methodology; UNESCO: Paris, France, 1978.

34. Hur, J.; Hwang, S.-J.; Shin, J.-K. Using synchronous fluorescence technique as a water quality monitoring tool for an urban river. Water Air Soil Pollut. 2008, 191, 231-243. [CrossRef] 
35. Hur, J.; Lee, B.-M.; Shin, H.-S. Microbial degradation of dissolved organic matter (DOM) and its influence on phenanthrene-DOM interactions. Chemosphere 2011, 85, 1360-1367. [CrossRef] [PubMed]

36. Porter, K.; Feig, Y. The use of DAPI for identification and enumeration of bacteria and blue-green algae. Limnol. Oceanogr. 1980, 25, 943. [CrossRef]

37. Park, B.S.; Wang, P.; Kim, J.H.; Kim, J.-H.; Gobler, C.J.; Han, M.-S. Resolving the intra-specific succession within Cochlodinium polykrikoides populations in southern Korean coastal waters via use of quantitative PCR assays. Harmful Algae 2014, 37, 133-141. [CrossRef]

38. Lane, D. 16S/23S rRNA sequencing. In Nucleic Acid Techniques in Bacterial Systematics; Stackebrandt, E., Goodfellow, M., Eds.; John Wiley and Sons: Chichester, UK, 1991; pp. 115-175.

39. Turner, S.; Pryer, K.M.; Miao, V.P.; Palmer, J.D. Investigating deep phylogenetic relationships among cyanobacteria and plastids by small subunit rRNA sequence analysis. J. Eukaryot. Microbiol. 1999, 46, 327-338. [CrossRef] [PubMed]

40. Fadrosh, D.W.; Ma, B.; Gajer, P.; Sengamalay, N.; Ott, S.; Brotman, R.M.; Ravel, J. An improved dual-indexing approach for multiplexed 16S rRNA gene sequencing on the Illumina MiSeq platform. Microbiome 2014, 2, 6. [CrossRef]

41. Wishart, D. Note: An algorithm for hierarchical classifications. Biometrics 1969, 256, 165-170. [CrossRef]

42. Ter Braak, C.J. The analysis of vegetation-environment relationships by canonical correspondence analysis. Vegetatio 1987, 69, 69-77. [CrossRef]

43. Saraceni, C.; Ruggiu, D. Techniques for sampling water and phytoplankton. In A Manual on Methods for Measuring Primary Production in Aquatic Environments; Blackwell Scientific: Philadelphia, PA, USA, 1969; pp. 5-7.

44. Borja, V.M. Marine Phytoplankton of the Western Pacific; Kouseisha Kouseikaku: Tokyo, Japan, 2012.

45. Makoto, O.; Tsutomu, I. Methods in Marine Zooplankton Ecology; John Wiley: Hoboken, NJ, USA, 1984.

46. McNichol, A.P.; Aluwihare, L.I. The power of radiocarbon in biogeochemical studies of the marine carbon cycle: Insights from studies of dissolved and particulate organic carbon (DOC and POC). Chem. Rev. 2007, 107, 443-466. [CrossRef]

47. Maranón, E.; Cermeno, P.; Fernández, E.; Rodríguez, J.; Zabala, L. Significance and mechanisms of photosynthetic production of dissolved organic carbon in a coastal eutrophic ecosystem. Limnol. Oceanogr. 2004, 49, 1652-1666. [CrossRef]

48. Caballero, M.A.; Jallet, D.; Shi, L.; Rithner, C.; Zhang, Y.; Peers, G. Quantification of chrysolaminarin from the model diatom Phaeodactylum tricornutum. Algal Res. 2016, 20, 180-188. [CrossRef]

49. Hildebrand, M.; Manandhar-Shrestha, K.; Abbriano, R. Effects of chrysolaminarin synthase knockdown in the diatom Thalassiosira pseudonana: Implications of reduced carbohydrate storage relative to green algae. Algal Res. 2017, 23, 66-77. [CrossRef]

50. Ball, S.G.; Morell, M.K. From bacterial glycogen to starch: Understanding the biogenesis of the plant starch granule. Annu. Rev. Plant Biol. 2003, 54, 207-233. [CrossRef]

51. Benner, R.; Pakulski, J.D.; McCarthy, M.; Hedges, J.I.; Hatcher, P.G. Bulk chemical characteristics of dissolved organic matter in the ocean. Science 1992, 255, 1561-1564. [CrossRef]

52. Engel, A.; Harlay, J.; Piontek, J.; Chou, L. Contribution of combined carbohydrates to dissolved and particulate organic carbon after the spring bloom in the northern Bay of Biscay (North-Eastern Atlantic Ocean). Cont. Shelf Res. 2012, 45, 42-53. [CrossRef]

53. Myklestad, S.M.; Børsheim, K.Y. Dynamics of carbohydrates in the Norwegian Sea inferred from monthly profiles collected during 3 years at 66 N, 2 E. Mar. Chem. 2007, 107, 475-485. [CrossRef]

54. Sannigrahi, P.; Ingall, E.D.; Benner, R. Cycling of dissolved and particulate organic matter at station Aloha: Insights from 13C NMR spectroscopy coupled with elemental, isotopic and molecular analyses. Deep Sea Res. Part I Oceanogr. Res. Pap. 2005, 52, 1429-1444. [CrossRef]

55. Ogawa, H.; Tanoue, E. Dissolved organic matter in oceanic waters. J. Oceanogr. 2003, 59, 129-147. [CrossRef]

56. Lancelot, C.; Fasham, M.; Legendre, L.; Radach, G.; Scott, M.; Kirchman, D.L. Dissolved Organic Matter in Biogeochemical Models of the Ocean, Towards a Model of Ocean Biogeochemical Processes; Springer: Berlin, Germany, 1993; pp. 209-225.

57. Norrman, B.; LiZweifel, U.; Hopkinson, C.; Fry, B. Production and utilization of dissolved organic carbon during an experimental diatom bloom. Oceanogr. Lit. Rev. 1996, 5, 451-452. [CrossRef] 
58. Ajani, P.A.; Kahlke, T.; Siboni, N.; Carney, R.; Murray, S.A.; Seymour, J.R. The microbiome of the cosmopolitan diatom Leptocylindrus reveals significant spatial and temporal variability. Front. Microbiol. 2018, 9, 2758. [CrossRef]

59. Garcés, E.; Vila, M.; Reñé, A.; Alonso-Sáez, L.; Anglès, S.; Lugliè, A.; Masó, M.; Gasol, J.M. Natural bacterioplankton assemblage composition during blooms of Alexandrium spp.(Dinophyceae) in NW Mediterranean coastal waters. Aquat. Microb. Ecol. 2007, 46, 55-70.

60. Green, D.H.; Llewellyn, L.E.; Negri, A.P.; Blackburn, S.I.; Bolch, C.J. Phylogenetic and functional diversity of the cultivable bacterial community associated with the paralytic shellfish poisoning dinoflagellate Gymnodinium catenatum. FEMS Microbiol. Ecol. 2004, 47, 345-357. [CrossRef]

61. Jasti, S.; Sieracki, M.E.; Poulton, N.J.; Giewat, M.W.; Rooney-Varga, J.N. Phylogenetic diversity and specificity of bacteria closely associated with Alexandrium spp. and other phytoplankton. Appl. Environ. Microbiol. 2005, 71, 3483-3494. [CrossRef] [PubMed]

62. Jones, K.L.; Mikulski, C.M.; Barnhorst, A.; Doucette, G.J. Comparative analysis of bacterioplankton assemblages from Karenia brevis bloom and nonbloom water on the west Florida shelf (Gulf of Mexico, USA) using $16 \mathrm{~S}$ rRNA gene clone libraries. FEMS Microbiol. Ecol. 2010, 73, 468-485. [CrossRef]

63. Lafay, B.; Ruimy, R.; De Traubenberg, C.R.; Breittmayer, V.; Gauthier, M.J.; Christen, R. Roseobacter algicola sp. nov., a new marine bacterium isolated from the phycosphere of the toxin-producing dinoflagellate Prorocentrum lima. Int. J. Syst. Evol. Microbiol. 1995, 45, 290-296. [CrossRef]

64. Yang, C.; Li, Y.; Zhou, B.; Zhou, Y.; Zheng, W.; Tian, Y.; Van Nostrand, J.D.; Wu, L.; He, Z.; Zhou, J. Illumina sequencing-based analysis of free-living bacterial community dynamics during an Akashiwo sanguine bloom in Xiamen sea, China. Sci. Rep. 2015, 5, 8476. [CrossRef]

65. Sañudo-Wilhelmy, S.A.; Gómez-Consarnau, L.; Suffridge, C.; Webb, E.A. The role of B vitamins in marine biogeochemistry. Annu. Rev. Mar. Sci. 2014, 6, 339-367. [CrossRef]

66. Floodgate, G.; Hayes, P. The Adansonian taxonomy of some yellow pigmented marine bacteria. Microbiology 1963, 30, 237-244. [CrossRef]

67. Mudarris, M.; Austin, B. Systemic disease in turbot Scophthalmus maximus caused by a previously unrecognised Cytophaga-like bacterium. Dis. Aquat. Org. 1989, 6, 161-166. [CrossRef]

68. Williams, T.J.; Wilkins, D.; Long, E.; Evans, F.; DeMaere, M.Z.; Raftery, M.J.; Cavicchioli, R. The role of planktonic $\mathrm{F}$ lavobacteria in processing algal organic matter in coastal $\mathrm{E}$ ast A ntarctica revealed using metagenomics and metaproteomics. Environ. Microbiol. 2013, 15, 1302-1317. [CrossRef]

69. DeLong, E.F.; Franks, D.G.; Alldredge, A.L. Phylogenetic diversity of aggregate-attached vs. free-living marine bacterial assemblages. Limnol. Oceanogr. 1993, 38, 924-934. [CrossRef]

70. Pinhassi, J.; Sala, M.M.; Havskum, H.; Peters, F.; Guadayol, O.; Malits, A.; Marrasé, C. Changes in bacterioplankton composition under different phytoplankton regimens. Appl. Environ. Microbiol. 2004, 70, 6753-6766. [CrossRef] [PubMed]

71. Martin, M.; Barbeyron, T.; Martin, R.; Portetelle, D.; Michel, G.; Vandenbol, M. The cultivable surface microbiota of the brown alga Ascophyllum nodosum is enriched in macroalgal-polysaccharide-degrading bacteria. Front. Microbiol. 2015, 6, 1487. [CrossRef] [PubMed]

72. Bowman, J.P. The family colwelliaceae. In The Prokaryotes: Gammaproteobacteria; Springer: Berlin, Germany, 2014; pp. 179-195.

73. Michels, M.H.; Vaskoska, M.; Vermuë, M.H.; Wijffels, R.H. Growth of Tetraselmis suecica in a tubular photobioreactor on wastewater from a fish farm. Water Res. 2014, 65, 290-296. [CrossRef]

74. Powell, N.; Shilton, A.; Chisti, Y.; Pratt, S. Towards a luxury uptake process via microalgae-defining the polyphosphate dynamics. Water Res. 2009, 43, 4207-4213. [CrossRef]

75. Powell, N.; Shilton, A.N.; Pratt, S.; Chisti, Y. Factors influencing luxury uptake of phosphorus by microalgae in waste stabilization ponds. Environ. Sci. Technol. 2008, 42, 5958-5962. [CrossRef]

76. Yao, C.; Jiang, J.; Cao, X.; Liu, Y.; Xue, S.; Zhang, Y. Phosphorus enhances photosynthetic storage starch production in a green microalga (Chlorophyta) Tetraselmis subcordiformis in nitrogen starvation conditions. J. Agric. Food Chem. 2018, 66, 10777-10787. [CrossRef]

77. Legrand, C.; Rengefors, K.; Fistarol, G.O.; Graneli, E. Allelopathy in phytoplankton-biochemical, ecological and evolutionary aspects. Phycologia 2003, 42, 406-419. [CrossRef]

78. Imai, I.; Ishida, Y.; Sakaguchi, K.; Hata, Y. Algicidal marine bacteria isolated from northern Hiroshima Bay, Japan. Fish. Sci. 1995, 61, 628-636. [CrossRef] 
79. Imai, I.; Kimura, S. Resistance of the fish-killing dinoflagellate Cochlodinium polykrikoides against algicidal bacteria isolated from the coastal sea of Japan. Harmful Algae 2008, 7, 360-367. [CrossRef]

80. Kang, Y.-H.; Jung, S.W.; Joo, J.-H.; Han, M.-S. Use of immobilized algicidal bacteria to control natural freshwater diatom blooms. Hydrobiologia 2012, 683, 151-162. [CrossRef]

81. Kim, J.H.; Park, J.H.; Song, Y.H.; Chang, D.S. Isolation and characterization of the marine bacterium, Alteromonas sp. SR-14 inhibiting the growth of diatom, Chaetoceros species. Korean J. Fish. Aquat. Sci. 1999, 32, 155-159.

82. Lee, B.-K.; Katano, T.; Kitamura, S.-I.; Oh, M.-J.; Han, M.-S. Monitoring of algicidal bacterium, Alteromonas sp. Strain A14 in its application to natural Cochlodinium polykrikoides blooming seawater using fluorescence in situ hybridization. J. Microbiol. 2008, 46, 274-282. [CrossRef] [PubMed]

83. Su, J.Q.; Yang, X.R.; Zheng, T.L.; Tian, Y.; Jiao, N.Z.; Cai, L.Z.; Hong, H.S. Isolation and characterization of a marine algicidal bacterium against the toxic dinoflagellate Alexandrium tamarense. Harmful Algae 2007, 6, 799-810. [CrossRef]

(C) 2020 by the authors. Licensee MDPI, Basel, Switzerland. This article is an open access article distributed under the terms and conditions of the Creative Commons Attribution (CC BY) license (http://creativecommons.org/licenses/by/4.0/). 